\title{
Box Girder Construction on Toll Road Project use Manual Program Evaluation and Review Technique (M-PERT) and Value Engineering (VE) to Performance Cost and Time Improvement
}

\author{
Albert Eddy Husin ( $\sim$ albert_eddy@mercubuana.ac.id) \\ Universitas Mercu Buana https://orcid.org/0000-0003-0163-928X \\ Diah Ika Rahmawati \\ Universitas Mercu Buana \\ Myrna Meisaroh \\ Universitas Mercu Buana \\ Bernadette Detty Kussumardianadewi \\ Universitas Mercu Buana
}

Research

Keywords: highway, box girder, m-pert, value engineering, time and cost-efficiency

Posted Date: December 4th, 2020

DOl: https://doi.org/10.21203/rs.3.rs-117800/v1

License: (c) (i) This work is licensed under a Creative Commons Attribution 4.0 International License.

Read Full License 

Technique (M-PERT) and Value Engineering (VE) to Performance Cost and Time Improvement

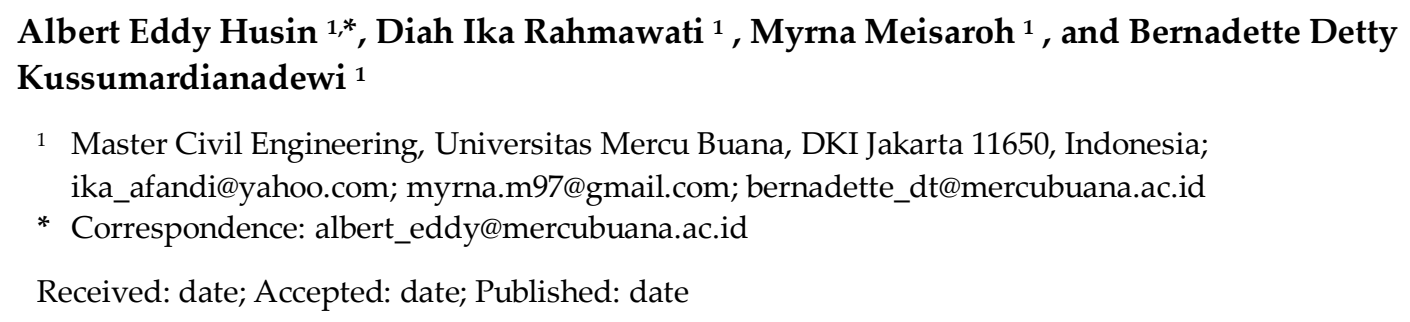

\begin{abstract}
Indonesia's ranking is 72 out of 141 countries and is in 5th place in the group of countries in Southeast Asia based on the 2019 Global Competitiveness Index (GCI) by the World Economic Forum. The current development of infrastructure development is not directly proportional to an increase in the number of infrastructure users by $1.9 \%$ from an annual increase of $10 \%-55 \%$. And the occurrence of implementation time experienced a delay of $11.95 \%$. And with a low rate of return on books with high investment costs in the construction of $7.79 \%$. The expected goal in this research is to have cost and time efficiency in implementing infrastructure development. In this study, the focus is on the upper structure work, one of which is the box girder, to improve time and cost efficiency based on the Manual Program Evaluation and Review Technique (M-PERT) and Value Engineering (VE) in the case study of this research. The case study using the M-PERT method resulted in a time efficiency value of $98.87 \%$ of the completion time at the job site, while the VE method obtained an added value of income outside toll roads of $9.38 \%$ of construction costs.
\end{abstract}

Keywords: highway; box girder; m-pert; value engineering; time and cost-efficiency

\title{
1. Introduction
}

Infrastructure development is the main target of government programs, as evidenced directly by making infrastructure development one of the main strategic issues and targets or a general infrastructure target that must be worked on. This development is the main target because Indonesia's ranking is 72 out of a total of 141 countries with a competitiveness score at the 67.7 level based on the World Economic Forum on the Global Competitiveness Index (GCI) activity in 2019 and is in 5th place in the Asian Region. Southeast (ASEAN).

The infrastructure sector, as one of the primary drivers in stimulating economic growth and developing inclusivity in Indonesia, has been upgrading and equitably expanding throughout the country to reduce logistics costs, reduce the gap between eastern and western Indonesia, increase economic growth and also reduce poverty. Based on the Visium 2030 set by The Ministry of Public Works and Housing, it is projected that the investment needs to meet the requirement for infrastructure development in 2020-2024.

Based on the National Medium-Term Development Plan (RPJMN) 2020-2024 [2], the expected target is to create an independent, advanced, just, and prosperous Indonesian society through accelerating development in various fields by emphasizing the flying of a strong economic structure based on competitive advantages in various regions. supported by quality and competitive human resources. Of the targeted construction of new toll roads spanning 2,500 km spread over 78 development projects. Starting from the toll road works, more and more toll road projects are being carried out, which are always part of each project, namely Cost, Quality (Performance), and Time. 


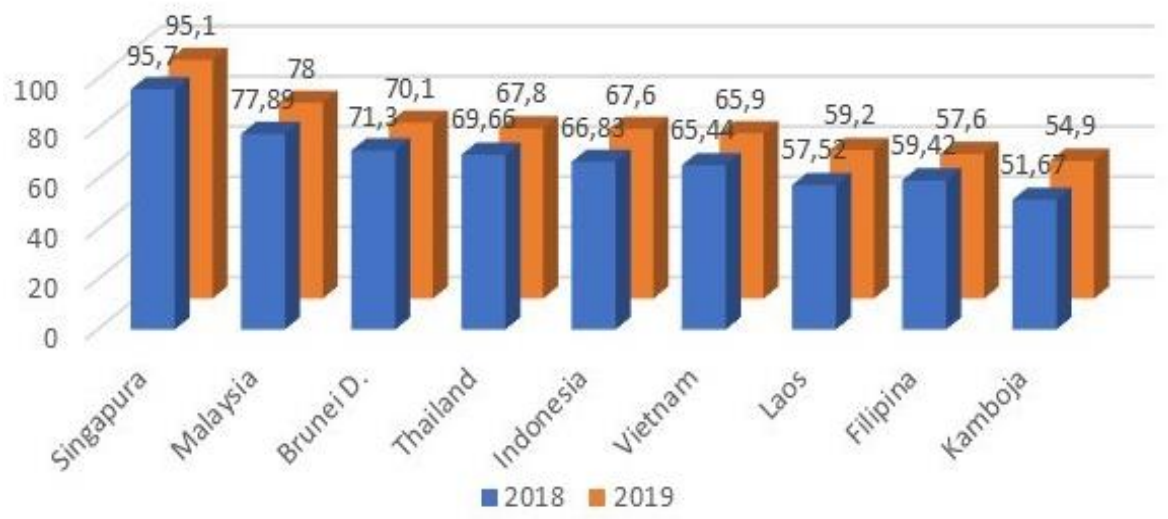

Figure 1. ASEAN Country Infrastructure Competitiveness Ranking Score [1].

Also, it can increase Indonesia's economic competitiveness from the aspect of infrastructure development. Efficient and extensive infrastructure aims to ensure the effectiveness of the functioning of the economy. Infrastructure development is expected to increase accessibility, increase the competitiveness of a region, and integrate domestic and international markets with competitive costs in a timely manner [3]. In realizing this, it is in the development of infrastructure if transportation is smooth between one area and another, in the form of land, sea, and air transportation. At this time, toll road infrastructure constitutes an adequate land transportation infrastructure or serves for the movement of people or goods which is quite efficient in terms of travel time and distance. According to [4], the development of population growth causes a reduction in the road network caused by an increase in the number of vehicles which continues to increase every year, ranging from $10 \%-55 \%$ per year and is not balanced with the development of road length which is only around $1.9 \%$ per year.

With the plan for new toll roads in 2020-2024 almost 2 (two) times the plan for new toll roads in the 2015-2019 development planning, it is hoped that they will proceed according to the budgeted plan. In road works on the project, there are many theories that can be done, from data collected as many as 1,722 toll road projects taken from 1995 to 2001 by the Indiana Department of Transportation, the United States, which obtained $11.95 \%$ highway delays [5]. The high investment in toll road construction and the low rate of return on interest, which is only around $7.79 \%$, makes it difficult to attract private investors to participate in infrastructure development [6]. With any problems or constraints faced in infrastructure development later, it is hoped that in its implementation, a solution is needed to overcome delays in both the construction and operation of the toll road. This researcher will analyze the scheduling time efficiency using the Manual Program Evaluation and Review Technique (M-PERT) which gets a job optimization of 7,55\% from the initial work duration [7] and construction costs using Value Engineering (VE) which optimizes job financing by $8,32 \%[8]$.

The construction of toll roads is not much different from the construction of elevated roads, the difference is that there are no two-wheeled vehicles. Where the construction of the intersection is parallel to the construction of laying roads at a cost of around 175 million $\mathrm{THB}$, to increase the capacity of the intersection and reduce vehicle delays and long queues, and the flyover is one that supports a traffic volume of around 25,000-45,000 vehicles/day [9].

In the construction of this infrastructure, in its implementation, handling is required that there is no delay in both the construction and operation of the toll road. In implementing a project, there are several risk factors and uncertainties experienced in the implementation process. However, in a toll road construction project, it must consider the objectives of the work where the implementation is a process that is repeated continuously with the same pattern so that it is necessary to optimize the implementation time and construction costs. In the implementation of construction, the biggest time and cost is on the structural work, both the upper and lower structures. In this study, the construction of the upper structure in the form of a box girder has the greatest influence on the overall construction implementation. 
With this, it is expected that using the M-PERT and VE methods can optimize the construction time and costs. The following are some of the assumptions or problem formulations in this study as follows:

- How to implement the M-PERT and VE method to the work of box girder on toll road projects?

- What is the result of the implementation of M-PERT and VE on the study case of box girder work on toll road projects?

\section{Materials and Methods}

The discussion of this research methodology will be conducted to analyze the implementation and quality usually can be overcome with the application of the suitable technology and equipment, while the aspect of work safety can be handle with the proper implementation of safety management program especially in the field [10]. Implementation M-PERT and VE methods and their effects on improving time and cost performance on box girder work on toll road projects, as well as identifying the factors that most influence the success (critical success factor) of the implementation of the Mmethod. PERT and VE in improving time and cost performance on box girder work on toll road projects.

This research is formulated using a combination of two research methods, namely quantitative experimental methods and qualitative methods (with statistical analysis). Quantitative methods experiments are carried out by simulating the implementation of the M-PERT and VE methods on the research object (or called the implementation case study), which is based on the implementation procedure obtained from previous literature studies.

\subsection{Method of collecting data}

This study will use two (2) types of data, namely; primary data, which is obtained from questionnaire surveys and focus group discussions as well as secondary data, which is obtained from the results of literature studies such as books, references, journals, and other research related to the research being carried out. The questionnaire survey was distributed to respondents through distribution both offline.

\subsubsection{Questionnaire Survey}

The purpose of this questionnaire survey is to obtain an overview of the stakeholders perceptions of finishing work, namely project manager, site manager, or the equivalent of additional functions, major risks, and key success factors in finishing high-rise buildings. This activity starts with compiling the research variables into a draft questionnaire. The type of questionnaire that is structured is a questionnaire in the form of closed-ended questions that already have a set of answers that can be selected by the respondent. The answer model for this questionnaire is Multiple-choice. Multiple-choice; It is used to find out the ranking of several things you want to measure, in which there are several answer options and the respondent may choose one or more of the available answer options.

\subsubsection{Data Tabulation}

Based on the data that has been collected from questionnaires distributed to respondents as described in the previous section, tabulation of the data was carried out to facilitate the analysis process. Data tabulation is intended for entering data from certain tables and arranging the numbers and calculating them. There are two types of tables that are often used, namely data tables and work tables. Data tables are tables that are used to describe data, making it easier for researchers to understand the structure of the data. While the worktable is a table used to analyze the data contained in the data table. 
The analysis used follows the implementation flow as shown in Figure 2 for this implementation flowchart, as an effort to assess the improvement in time and cost performance 134 based on M-PERT \& VE on the research object.

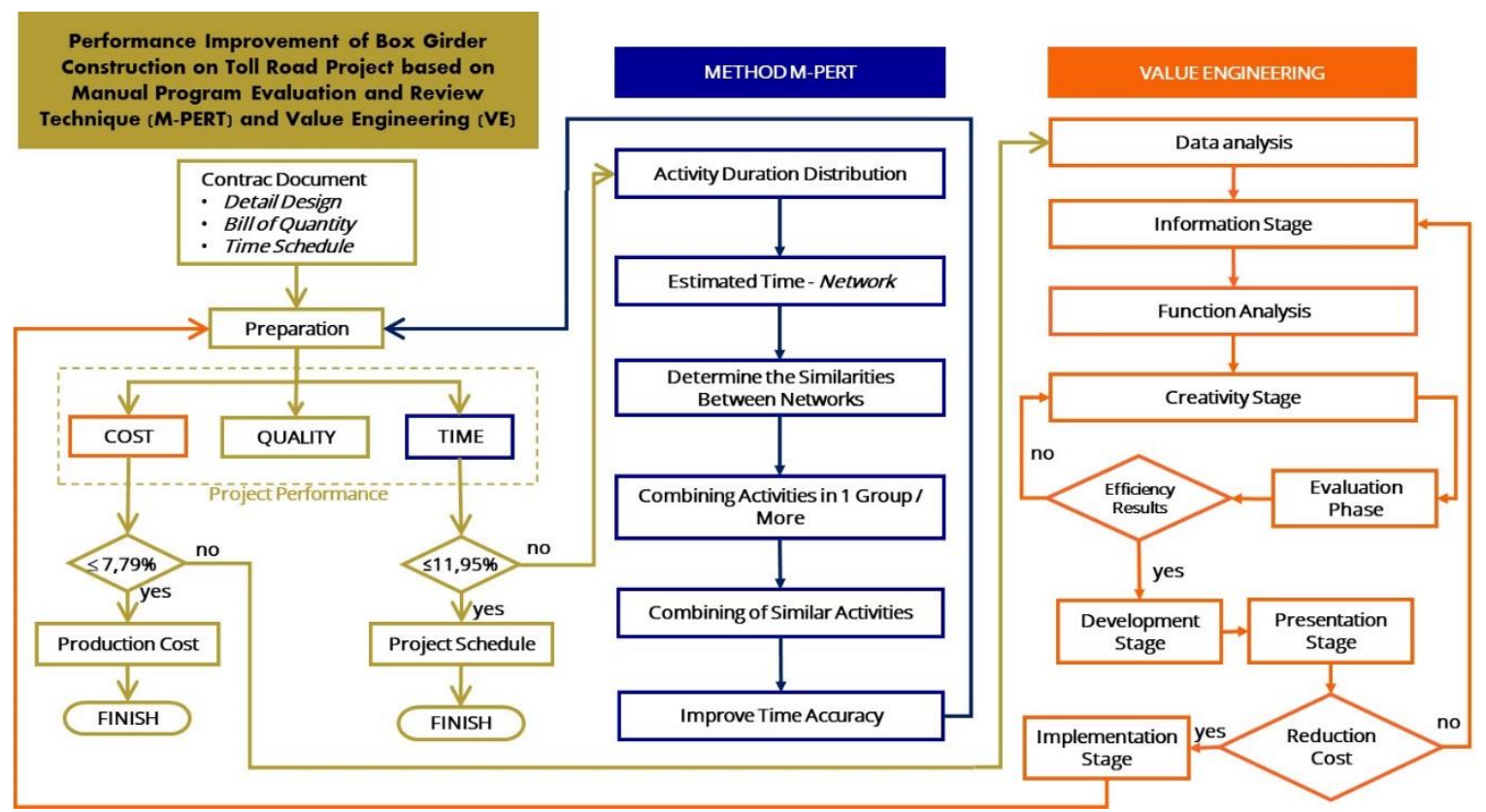

Figure 2. Flowchart of the Implementation of Time and Cost Performance Improvement Based on M-PERT and VE

\section{7}

\subsubsection{Manual Program Evaluation and Review Technique (M-PERT)}

In this study, the method used in this study was the Manual Program Evaluation and Review Technique (M-PERT) method. In determining the success of a project, the stage of quality maintenance to remain at a predetermined standard, there needs to be supervision and emphasis on the sustainability of a construction project. These stages include:

- $\quad$ The planning stage needs a quality planning procedure (quality planning)

- $\quad$ The implementation phase needs quality assurance (quality assurance)

- The evaluation stage needs control of quality (quality control),

- Maintenance stage and quality development (quality Improvement)

Emphasis on these four stages has been carried out on any construction project with the assumption that the better the quality, the higher the level of customer satisfaction (customers), and the return (major returns) to the capital invested in the project will be higher.

The M-PERT method was first introduced by Pablo Ballesteros Perez, Ph.D. published in the American Society of Civil Engineers (ASCE) in June 2017. In this journal, a case study analysis was carried out on bridgework using the PERT method, and a Manual Program Evaluation and Review Technique (M-PERT) was carried out. The aim was to update PERT and propose a new redefined technique named M-PERT, which deals with the most relevant weaknesses of the original technique (event incorporation bias), enables manual computation, and adds a new and interesting set of features that the original technique lacked. M-PERT allows modeling of much more representative real-life projects and helps to schedule students to understand more intuitively the basic concepts of scheduling when activities have uncertain duration [11].

Essentially, M-PERT recursively streamlines the schedule network by combining activities in series and parallels. M-PERT has been built on five models. Most of which share some specific traits (marked with an X). All five methods utilize the activity-on-arc (AoA) network, whereas M-PERT uses activity-on-node (AON) because it is more user friendly for practitioners and more commonly 
found in software (e.g., Microsoft Project, Primavera Astrologers). M-PERT makes exclusive use of the AON network with a preferred finish-start (FS) link. Steps on the application of M-PERT in bridgework [11].

M-PERT is a reduction technique in which project activities are combined by groups of two or more, resulting in new single merger activity. The challenge of using M-PERT is how to precisely combine different activities (which ultimately correspond to a duration distribution). For that reason and justified earlier, it is assumed that the activity duration follows a normal distribution. Recognizing that certain probability distributions are almost insignificant, normal assumptions are also made by three of the five methods. CPM / PERT light network components show how interconnected one activity is with other activities in a project [11].

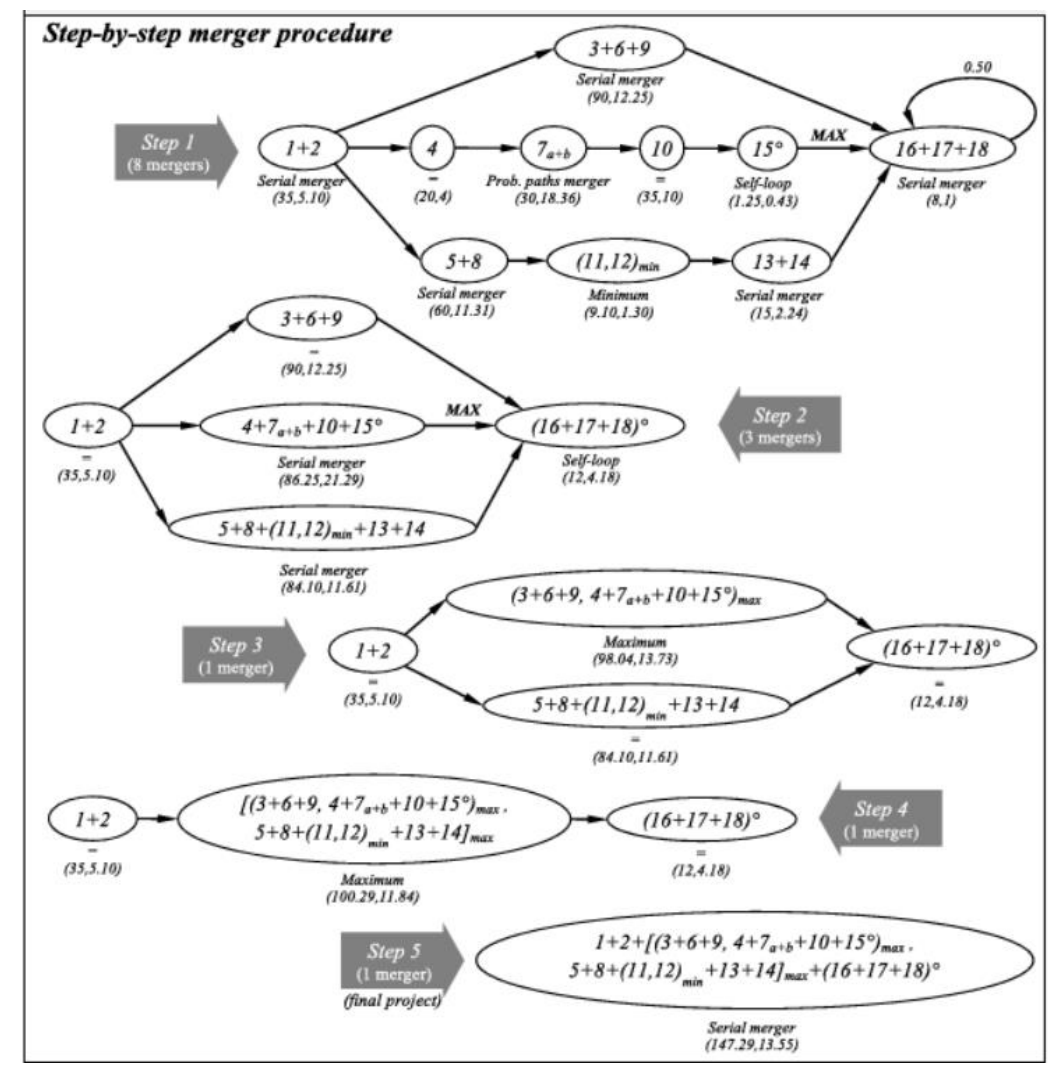

Figure 3. Activity Merger Steps [11].

This technique takes advantage of several methods proposed since the original PERT was introduced. In particular, in situations with multiple parallel paths (the norm in construction projects), the original PERT paid little attention to project duration and excessive variance. A systematic literature review has been prepared to justify M-PERT which concentrates on the significant weaknesses of PERT and to show why, regardless of other sinister aspects, the resulting tool is still accurate but uncomplicated. Indeed, the proposed method is easy to apply and easy to learn intuitive nature and simplifies assumptions. This makes M-PERT an attractive tool for teaching the basics of scheduling for construction and project management, especially since the calculations can be developed manually or in a very simple spreadsheet manner [11]. Based on [12] the steel construction project in the case study 63 days of project planning time. Calculated with PERT or a critical path of 69.3 days. And Actual length of work 66 days. It means a difference of 3.3 days compared to the actual time on-site or has accurate 95,24\%. Calculations are based on MPERT 66.74 days. It means a difference of 0.74 days compared to the actual time on-site or has an accurate $98.89 \%$. 


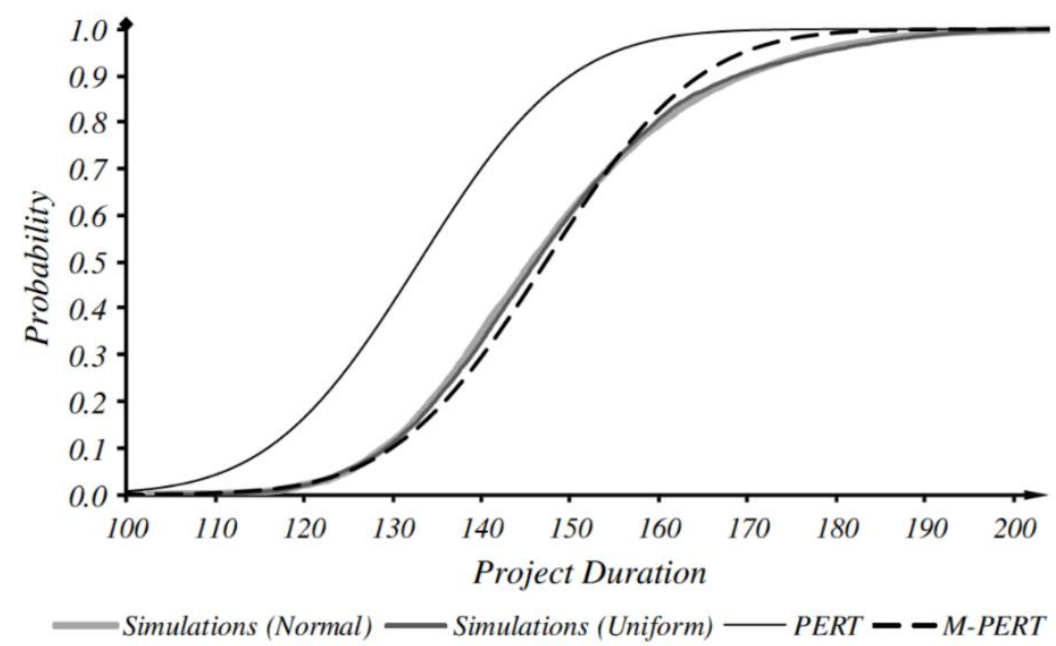

Figure 4. Comparison of the accuracy of project duration estimates between the normal, PERT, and M-PERT distributions [11].

\subsubsection{Value Engineering (VE)}

Value Engineering was introduced in Indonesia in 1986 by Dr. Ir. Suriana Chandra. After the introduction of value engineering in the building construction industry in Indonesia for more than 30 years, it has not shown any encouraging development. This does not only happen in Indonesia, but the application of value engineering in the world of building construction in Southeast Asia has not developed properly.

Value Engineering or value engineering in this research is used to identify additional functions as innovation so that it can form an alternative conceptual design model that leads to an increase in the economic value added to infrastructure projects. In a brief description of the development of value engineering published in the standard book SAVE International [13], it is implied that the philosophy of value engineering makes it easy for efforts to understand the concept of value engineering, there are stages/phases in planning Value Engineering activities, namely: 1) the information gathering stage, 2) the function analysis stage, 3) the creativity and innovation stage, 4) the development stage, 5) the decision analysis stage, 6) the decision-making stage, 7) the implementation stage, 8 ) the recommendation stage, 9) the results research.

According to SAVE International, value engineering is not just about analyzing costs, but means that value engineering is:

- System oriented (System Oriented) formal work plan to identify and eliminate unnecessary costs (Unnecessary Cost).

- Multidisciplinary group approach (Multidisciplinary Team Approach) consisting of experienced planners and value engineering consultants.

- Life Cycle Oriented calculates the total costs over the life cycle of the project including the total costs to own and operate the facility.

- A proven management technique (A Proven Management Technique).

- Functional orientation (Function Oriented) relates the desired functions to the values received

The relationship between value, cost, and function according to [14] is a value that cannot be determined only by considering the subject itself, therefore the team must first determine a value measurement tool [15]. The performance of each component should be measured with this measuring instrument. According to the standard SAVE [13] the main concept of value engineering methodology lies in value (value). Value (value) is a statement of the relationship between functions and resources. In general, the value is described as follows [15].

$$
\text { Value }=\frac{\text { Function }}{\text { Cost }}
$$


Where the function is measured by the performance required by the customer and the resource is measured in the amount of material, labor, price, time, and others needed to complete the function. states that the main concept of the value engineering method lies in the value, function, and cost where the relationship is formulated as follows. [16] states that the main concept of the VE methodology lies in the value, function, and cost where the relationship is formulated in the following equation:

$$
\text { Value }=\frac{\text { Function }+ \text { Quality }}{\text { Cost }}
$$

The benefits of the value engineering program have resulted in various improvements to the project/system/product and the achievement of values that have been widely used in developed countries and produced extraordinary effects (In-Chi-Sung, 2009). Major improvements have been achieved in return on project capital investment of $50 \%$ in construction projects in the UK (www.ivm.org.uk) as well as savings on public project costs of up to $25 \%$ of the total cost of large projects in the United States ( www.value-eng.org).

The value engineering process is called a value engineering study, which is a sequence of activities in the value study carried out for an object (project, process, product) which includes defining functions, developing and evaluating ideas that will produce a value engineering proposal and is held in the form of a workshop [17]. This value engineering study to conduct value engineering studies according to SAVE 2007 is divided into 3 levels as follows: 1) Pre-Study Stage (Pre-Workshop Study), 2) Study Stage (Value Job Plan), and 3) Post-Study Stage (Post Workshop Study). In value engineering, all ideas can be compared based on LCC, the value of all alternatives is defined to produce the same basic function or set of functions. The cost elements calculated include:

- Initial costs consisting of: building costs (item cost); development costs (development cost); implementation cost (implementation cost); miscellaneous costs.

- Annual Recurring Costs consist of operational costs.

\section{Results}

The research used for the validation of the case study was the Construction of Bekasi - Cawang Kampung Melayu Toll Road Works Section 1: STA $1+011$ - STA $11+501$ which is located on a national road that connects Bekasi City in West Java Province with the City of Jakarta, capable again and not in balance with the development and volume growth of vehicles passing the road, resulting in frequent congestion and disrupting the distribution of people and goods. For this reason, the construction of the Becakayu Toll Road is one solution so that congestion that occurs in the connecting areas between these areas can be resolved. This study is limited to the construction stage from the perspective of consultants and contractors on the work of the upper structure of the box girder section. Where these research activities are generally carried out at the beginning of the project before starting even during the planning process so that the benefits can be felt to the stakeholders.

\subsection{Manual Program Evaluation and Review Technique (M-PERT)}

In this section, the author discusses the determination of the planning duration of the Bekasi Cawang - Kampung Melayu Toll Road Development project, especially in the pier to pier segment including the box girder using the M-PERT method which begins with making the project duration first. Planning the project duration starts with determining the duration of each activity in the work until finally determining the total project duration and its standard deviation. To solve this case study, what is done is making a network diagram for the activities carried out from the beginning to the last activity. The network diagram for the construction of the Bekasi - Cawang - Kampung Melayu toll road is divided into 2 main parts, namely (1) foundation work, and (2) structural work. The following are the stages of work items from the beginning to the end of the activities for foundation work and the following toll road construction structure works. 
The explanation for the job description in Figure 5 is in Table 1. With the creation of a predecessor network for the construction of the toll road. PERT is a time-oriented method that leads to probabilistic or probabilistic scheduling [18]. Also in this vein, some research has been connected to the crashing of PERT activities in order to fast-track project execution [19]. This method is a development of the PERT method, which was developed by Pablo Ballesteros-Perez, Ph.D. a lecturer at the School of Construction Management and Engineering, University of Reading, UK. This method was introduced in 2017 with the ability to optimize the duration of the project up to $8.8 \%$ with a bridge project [11]. At the following stages:

- Making a detailed schedule or schedule of stages of detailed work implementation.

- Calculation of the duration of each stage of work implementation.

- $\quad$ Schedule creation and project scheduling analysis.

- Merging stages of work implementation.

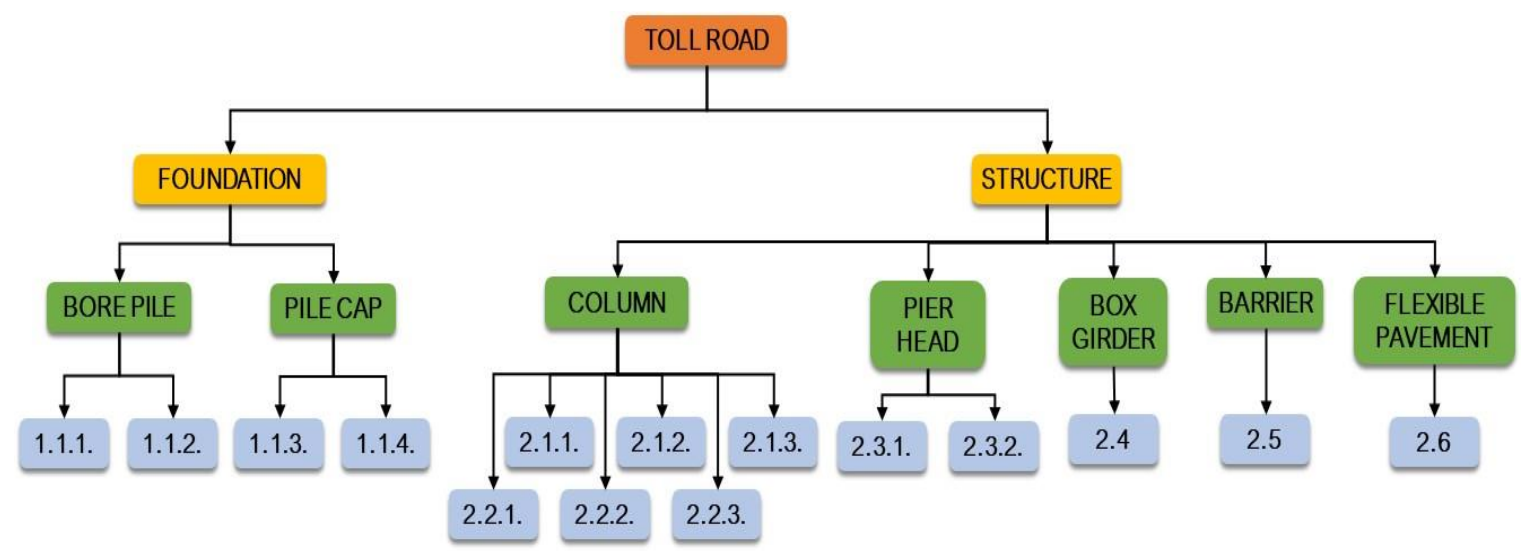

Figure 5. Bekasi - Cawang - Kampung Melayu Toll Road Construction Work Activities

Table 1. Activities Stage

\begin{tabular}{cc}
\hline Activity Code & Activity Description \\
\hline 1.1 .1 & Bore Pile Pier Work 1 \\
1.1.2 & Bore Pile Pier Work 2 \\
1.1.3 & Pile Cap Pier Works 1 \\
1.1.4 & Pile Cap Pier Works 2 \\
2.1 .1 & Pier 1 Column Work Phase 1 \\
2.1 .2 & Pier 1 Column Work Phase 2 \\
2.1 .3 & Pier 1 Column Work Phase 3 \\
2.2 .1 & Pier 2 Column Work Phase 1 \\
2.2 .2 & Pier 2 Column Work Phase 2 \\
2.2 .3 & Pier 2 Column Work Phase 3 \\
2.3 .1 & Pier Head Work 1 \\
2.3 .2 & Pier Head Work 2 \\
2.4 & Box Girder Jobs \\
2.5 & Barrier Work \\
2.6 & Flexible Pavement Work \\
\hline
\end{tabular}



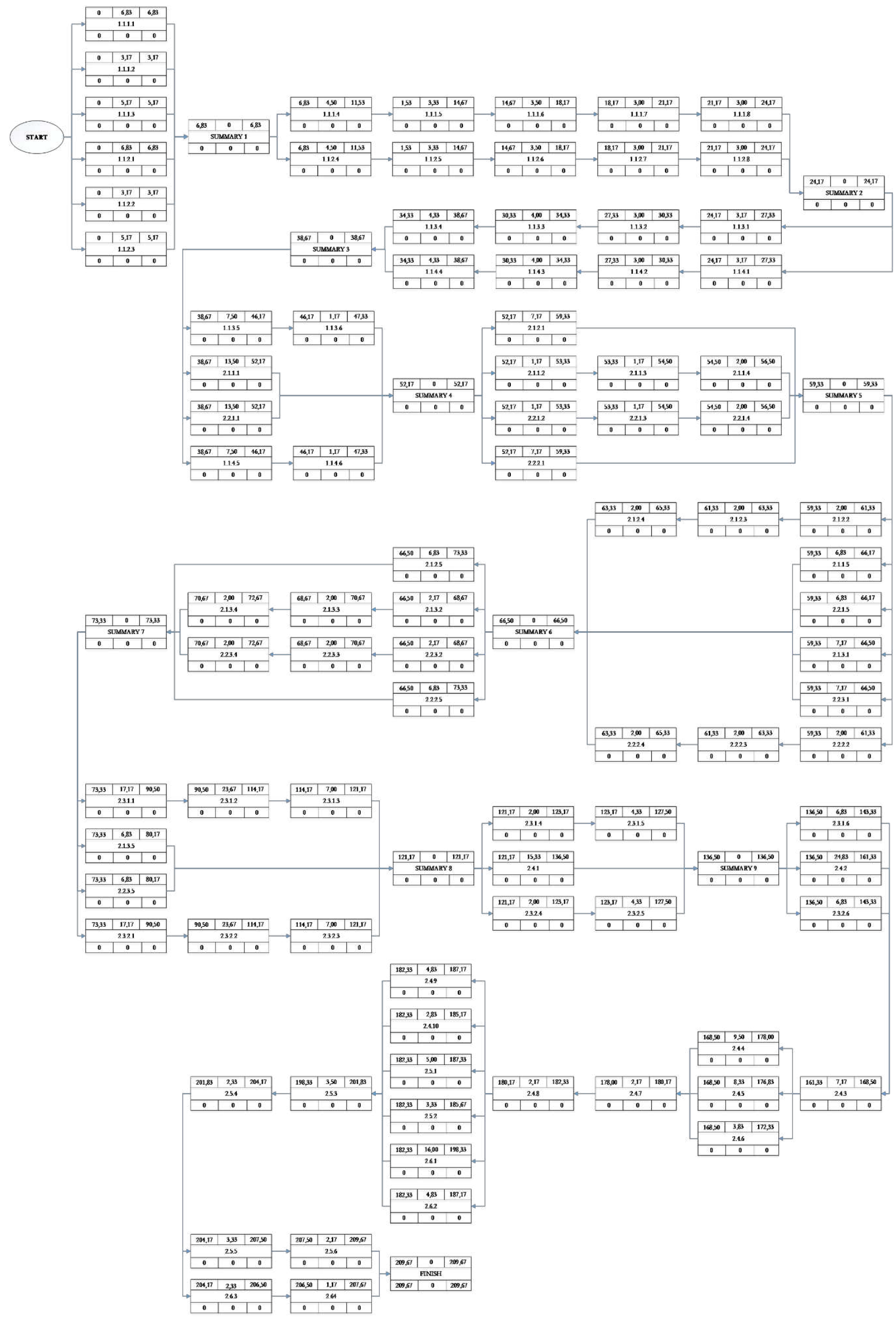

Figure 6. Precedence Diagramming Method 
After determining the implementation time based on the PERT method, it is continued by using the M-PERT method by starting the calculation of the duration of work balancing the estimated time between pessimistic time, moderate time, optimistic time to get the expected time with the following equation:

$$
t_{e}=\frac{t_{o}+\left(\begin{array}{lll}
4 & x & t_{m}
\end{array}\right)+t_{p}}{6}
$$

With a variation of each activity with the following equation:

$$
V=\left(\frac{t_{p}-t_{o}}{6}\right)^{2}
$$

The calculation of the correction rate for solving the standard deviation is corrected by the following equation:

$$
K=\sqrt{\frac{5}{7}+\left(\frac{16}{7} \times \frac{\left(t_{m}-t_{o}\right)\left(t_{p}-t_{m}\right)}{\left(t_{p}-t_{0}\right)^{2}}\right)}
$$

By using the equation above, it is obtained a simplification from the PERT diagram followed by using M-PERT which is based on the equation issued or applied by the discoverer [11]. obtained as many as 5 steps for the implementation of the toll road construction. The following is a diagram of the work from Step 1 to Step 5. As in the following picture.
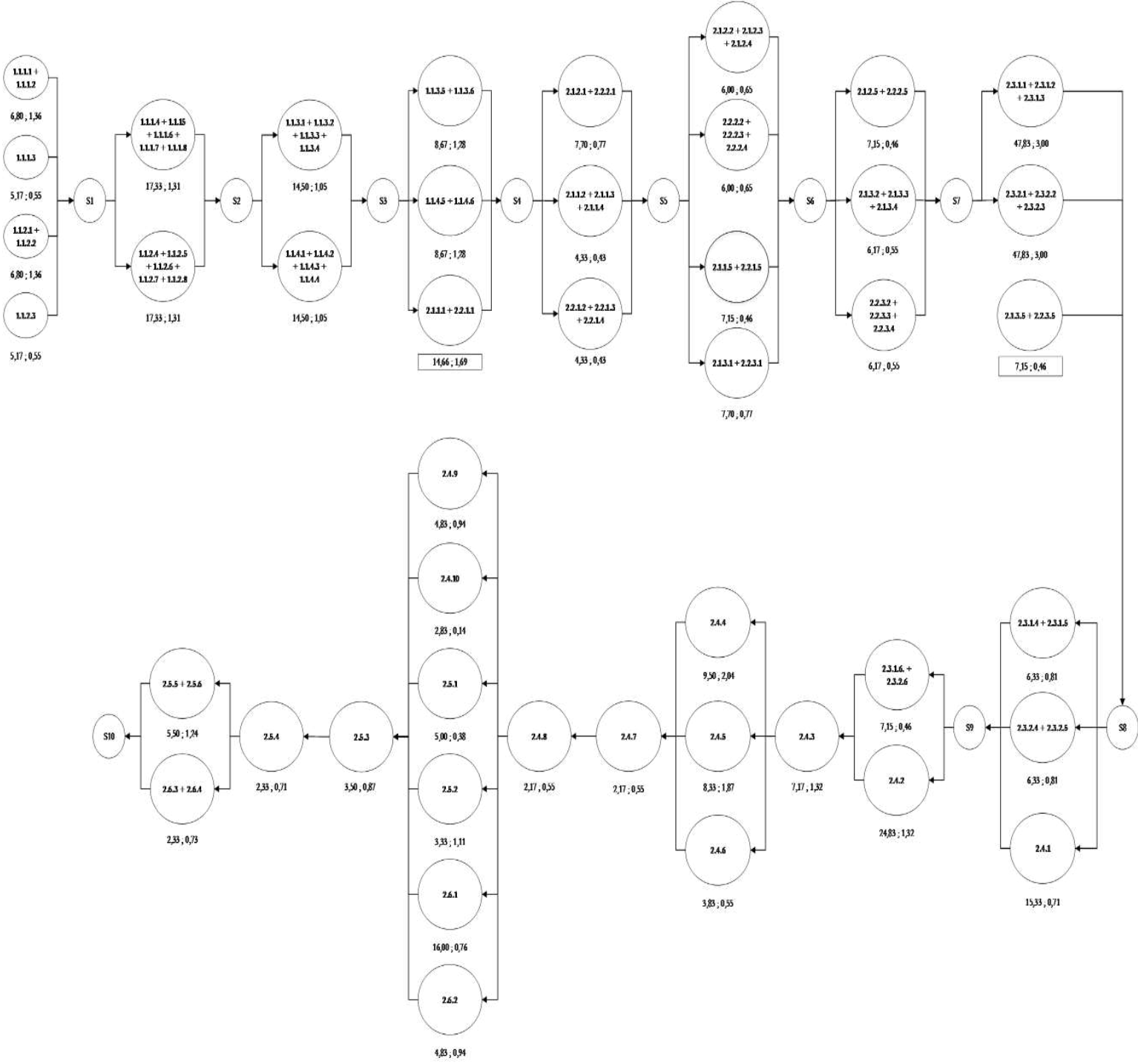


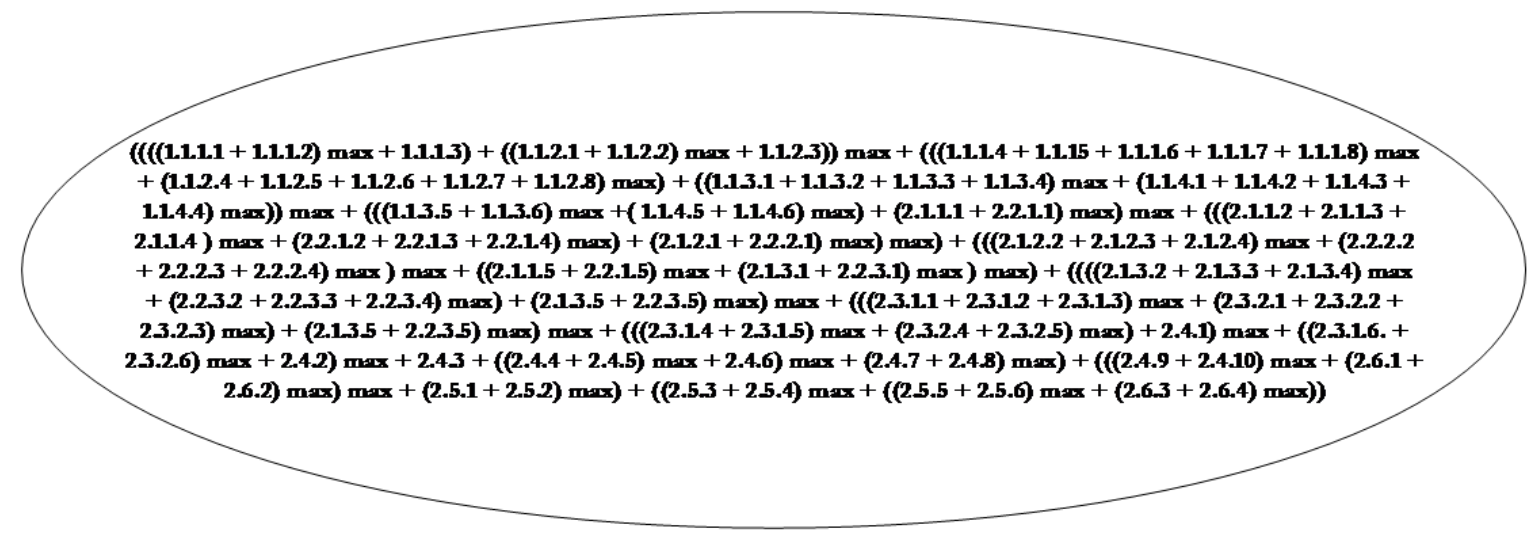

216,$52 ; 21,87$

Figure 8. Diagram M-PERT Step 5

With the equations and stages of using this method, the final results or summaries for job scheduling using the M-PERT method are obtained as listed in table 3.

\subsection{Value Engineering (VE)}

The goal of this research is to acquire any work items that are viable to be value-engineered [20].

Table 2. Result Metode M-PERT

\begin{tabular}{cccc}
\hline Activity & $\begin{array}{c}\text { Project Schedule } \\
\text { (day) }\end{array}$ & $\begin{array}{c}\text { M-PERT } \\
\text { (day) }\end{array}$ & $\begin{array}{c}\text { Realization } \\
\text { (day) }\end{array}$ \\
\hline Step 1 & & 212,16 & \\
Step 2 & & 215,92 & \\
Step 3 & 209 & 216,50 & 219 \\
Step 4 & & 216,52 & \\
Step 5 & & 216,52 & \\
\hline
\end{tabular}

And the results of the analysis carried out in this study showed that the accuracy of the job execution schedule was 3.5 days or $1.13 \%$ of the 219 days of toll road construction work. In some countries, it is $50 \%-50 \%$ this kind of practice encourages contractors to implement VE during construction. The goal of this research is to acquire any work items that are viable to be value-engineering [21]. Construction projects are explained, and by covering Bregana-Zagreb-Dubrovnik Motorway construction in Croatia by BECHTEL - ENKA joint venture as the sample project, practices of VE in this project are described. The satisfactory results of time and cost-saving are achieved by applying value engineering principles through the VE team during the project preparation phase and project revision phase.

Approximately $\$ 43,000,000$ and 12 months of time were saved in total thanks to all these VE works. This saving provided a builder company with $6 \%$ financial saving and $17 \%$ work time reduction [22]. And from a previous study [3] with a bridge object using an additional function is obtained the total revenues for the SSB project with the transportation function only or the "Do-Nothing" scenario is estimated to be US\$8,495.58 Million. The total revenues for the SSB project with additional functions or the "Do-Something" scenario is estimated to be US\$ 61,529.02 Million. The lifecycle cost analysis using the IRR and NPV approach confirms that the development of the SSB project with additional functions increases the Internal Rate of Return for the whole project by $7.56 \%$ that would provide a positive NPV value. So it can be ascertained that the financial viability of the SSB project would increase with additional functionality innovation. 
Following is also a previous study on high rise building work on retaining wall work items using the Value Engineering increased performance at the failure by the cost with savings of $18.83 \%$ [23].

The phase begins by determining the scope of the problem from the VE study then continues by identifying the functions of the Bekasi - Cawang - Kampung Melayu Toll Road Development based on the conditions of the existing design concept, including:

- Scope of the problem under study: Bekasi - Cawang - Kampung Melayu Toll Road Development Project for infrastructure in a highly vehicle-intensive area.

- Highest order function: stimulate economic growth in Bekasi - Cawang - Kampung.

- Lowest order function: generate income.

- Design objective: build connectivity infrastructure.

- Basic function: reduce congestion in Bekasi-Cawang-Kampung Melayu

- Defendant function: toll road components move people and goods, road structural components distribute loads.

- $\quad$ Processes: building roads, building foundations, building superstructures.

In this evaluation phase, it describes the main risk mitigation and the calculation of life cycle costs as a tool to evaluate the addition of the identified functions and explains how the mining function can add value to its function.

Creativity in this research is directed at developing functions that are integrated with their basic functions, by looking at all the potential that exists in the toll road development area, here are the results in the creativity phase, namely the potential for infrastructure efficiency with the idea of building oil pipes, gas pipes, fiber optics, and billboards. The results of this creativity become the material for making FAST Diagrams from the analysis of functions with the addition of Figure 9:

- Supporting functions: oil and gas distribution, transmitting data/telecommunication, installing billboards

- Supporting Processes: oil and gas development, fiber optic development, billboards construction.

The logical relationship between these functions can be seen in the following FAST diagram:

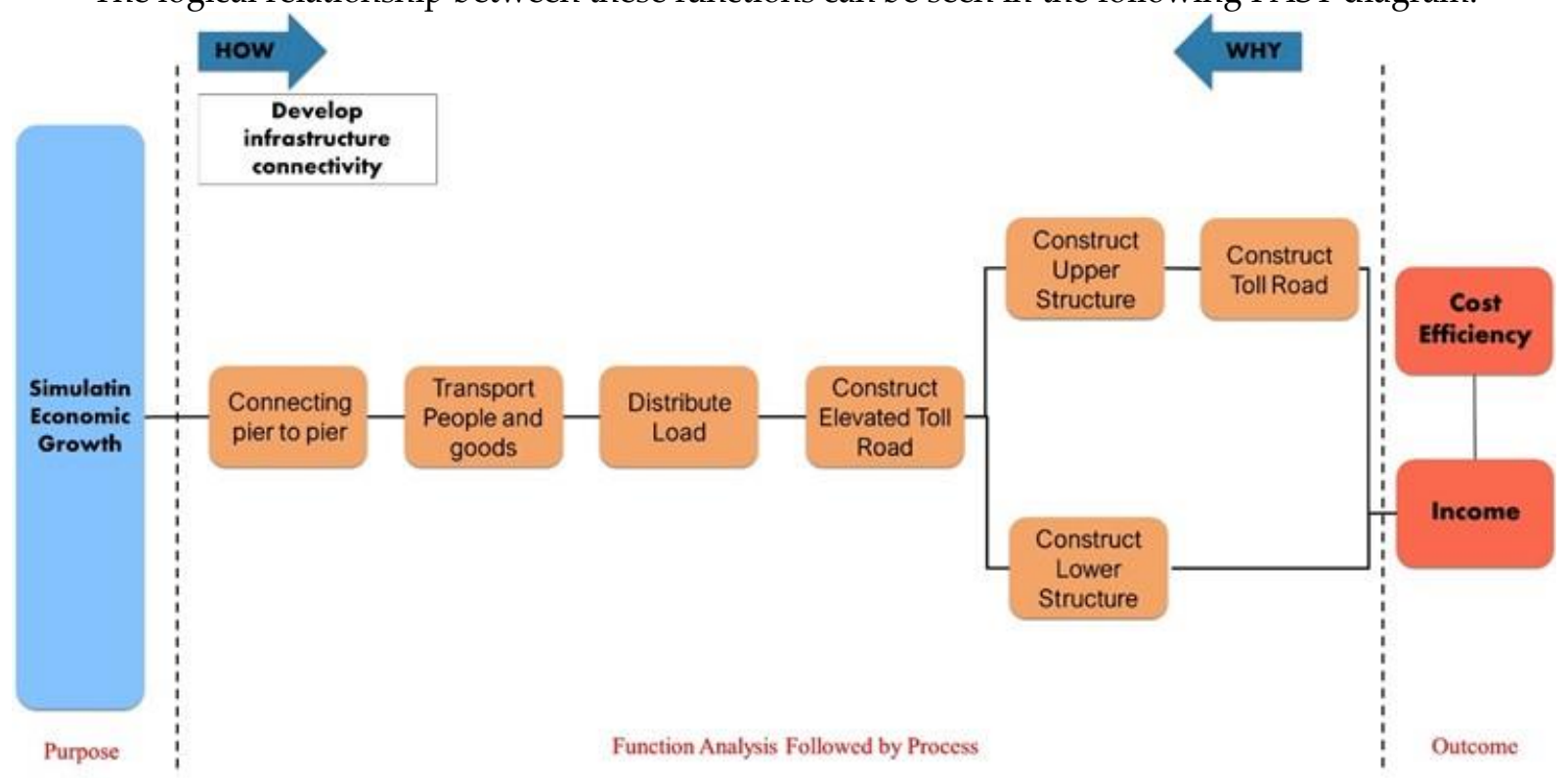




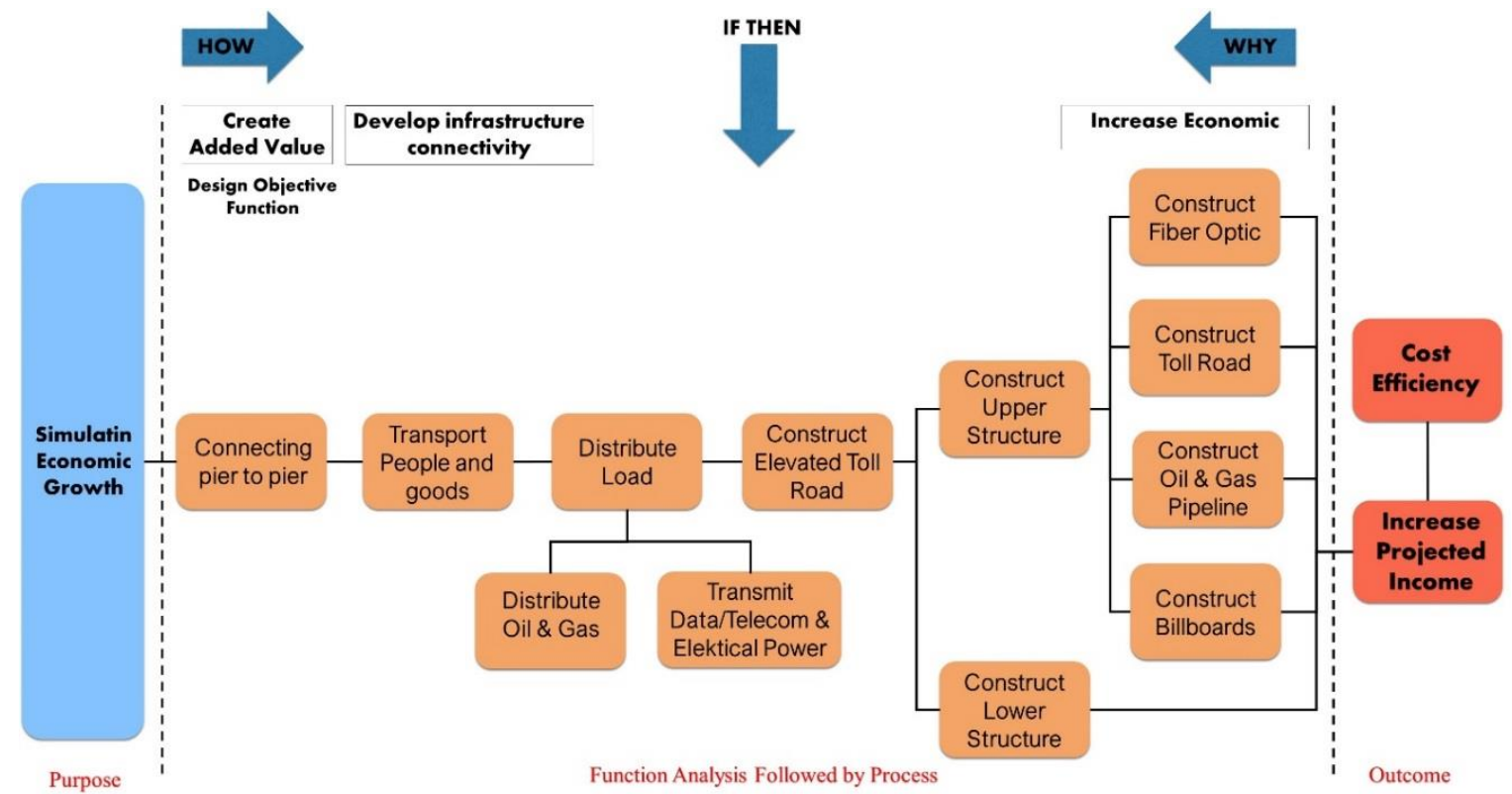

Figure 10. FAST Diagram of the Development of the Bekasi - Cawang - Kampung Melayu Toll Road

With the addition of functions on the toll road box girder, namely the addition of oil pipework, gas pipeline, fiber optic work, digital work (led boards). From these additions, the amount or value of the addition can be obtained from several literature and brochures and the lifetime for each additional function. The lifetime of work as follows:

Table 3. Lifetime Addition of Function

\begin{tabular}{lr}
\hline Addition of Function & Time (years) \\
\hline Oil Pipe & 15 \\
Gas Pipe & 15 \\
Fiber Optic Cables & 30 \\
Led & 12 \\
\hline
\end{tabular}

Based on Figure 9 and Table 3, from each additional function work, the development value or initial cost for each addition is obtained. From the calculation of the development financial analysis of the addition of functions, the NPV value, IRR value, and BCR value are obtained, as follows:

Table 4. Value-Added Cost of Functions

\begin{tabular}{ccccc}
\hline Item & $\begin{array}{c}\text { Initial Cost } \\
\text { (million rupiah) }\end{array}$ & $\begin{array}{c}\text { NPV } \\
\text { (million rupiah) }\end{array}$ & IRR & BCR \\
\hline Oil and Gas & 1.570 .603 & 8.149 .280 & $27,77 \%$ & 4,6 \\
Fiber Optic & 4.950 & 13.081 & $18,96 \%$ & 7 \\
Billboard & 1.315 & 9.210 & $19,96 \%$ & 15 \\
\hline
\end{tabular}

With this addition, the contribution of revenues outside the toll road was $9.83 \%$ of the toll road construction costs.

\section{Discussion}

With the results of using the M-PERT and VE methods in this study, it is hoped that the implementation time of infrastructure development in the future can be carried out according to the planned time and in financing this development, additional functions can be used in the infrastructure development so that the income and return of development capital are not fixed from 
the toll road revenue is instead assisted by contributions other than toll roads. With this time and cost efficiency, it does not depend too much on government funding. These results can be used as a basis or can be applied to infrastructure development that has not yet been built so that in the future each toll road business entity can calculate income other than those toll road users.

\section{Conclusions}

Based on the results of the research that has been done, it can be concluded that the results of the Research Question are as follows:

- Factors affecting the Manual Program Evaluation and Review Technique (M-PERT) and the Value Engineering (VE) method respectively are Image Documents, Work Time, Work Value, Percentage of Delays, Network Simplification, Combined Activities, Number of Network Benchmarks / Number of Activities, Good Planning, Value Engineering Development, and Cost Efficiency.

- From the research results, it was found that the percentage of M-PERT towards project scheduling was $1.13 \%$ with an accuracy of $98.87 \%$ and the implementation of VE obtained a contribution of revenues outside toll roads of $9.83 \%$ of the toll road construction costs.

- This hypothesis has been proven by statistical analysis and case study analysis by taking the research object on Toll Road Buildings.

Author Contributions: Conceptualization, A.E.H. dan D.I.R.; data curation, D.I.R. dan M.M.; writing-review and editing, D.I.R. dan M.M. All authors have read and agreed to the published version of the manuscript.

Funding: This research received no external funding.

Availability of data and materials: Not applicable

Acknowledgments: This research was supported by research grants from Mercu Buana University. It is necessary to have standardized research that formed equivalent perceptions among all parties involved in the construction process, particularly to toll road projects. This is to improve the schedule, and costs effectiveness, and accuracy of the project, so that the performance of structure works of toll road projects can be enhanced. Understandably, further research on the effect of the implementation of the M-PERT and VE method to the monitoring of the toll projects is crucial. Further research on the implementation of the M-PERT and VE method on other projects should also be conducted to support the conclusion of this study.

Conflicts of Interest: The authors declare no conflict of interest

\section{References}

1. Indonesia's Infrastructure Competitiveness Ranks Fifth in ASEAN 2019. Available online: https://databoks.katadata.co.id/datapublish/2019/10/11/daya-saing-infrastruktur-indonesia-urutan-kelima -di-asean (accessed on 5 October 2020).

2. National Medium-Term Development Plan (RPJMN) 2020-2024, Ministry of National Development Planning/National Development Planning Agency (BAPPENAS), 2020.

3. A. E. Husin, M. A. Berawi, S. Dikum, T. Ilyas, A. R. B. Berawi, "Forecasting Demand on Mega Infrastructure Projects: Increasing Financial Feasibility," Internasional Journal of Technology 2015, vol. 6, no. 1, pp. 73-88.

4. Waldijono, "Kajian Lalulintas Kota melalui Pendekatan Sistem," Indonesian Islamic University, 1992.

5. P.C. Anastasopoulos, S. Labi, A. Bhargava and F. L. Mannering, "An Empirical Assessment of The Likelihood and Duration of Highway Project Time Delay," Journal of Construction Engineering and Management, 2012, vol. 138, pp. 390-398.

6. M. A. Berawi, B. Susantono, P. Miraj, A. R. B. Berawi, H. Z. Rahman, Gunawan, A. Husin, "Enhamcing Value for Money of Mega Infrastructure Projects Development Using Value Engineering Method," Procedia Technology, 2014, vol 16, pp. 1037-1046.

7. A. E. Husin, Susandi, and B. D. Kussumardianadewi, "Time Performance Upgrade On Toll Road Construction Project By M-PERT Scheduling Implementation." International Journal of Current Research in Life Sciences, 2019, vol. 8, no. 1, pp. 3035-3042. 
8. R. S. Heralova, "Possibility of Using Value Engineering in Highway Projects," Procedia Engineering, 2016, vol 164, pp. 362-367.

9. IHT. (1997). Transport in the Urban Environment, Institut of Highway and Transportation, London.

10. A. Ali, M. Amin, and A. E. Husin, "Key Success Factors For Safety Programs Implemtation In Indonesia Construction Projects," International Journal of Civil Engineering and Technology (IJCIET), 2019, vol. 10, no. 2, pp. 1385-1394.

11. P. Ballesteros-Perez, "M-PERT: Manual Project-Duration Estimation Technique for Teaching Scheduling Basics," Journal of Construction Engineering and Management, 2017, vol. 143, no. 9, pp. 04017063.

12. A. E. Husin and B. D. Kussumardianadewi, "M-PERT and Lean Construction Integration on Steel Construction Works of Warehouse Buildings," International Journal of Engineering and Advanced Technology (IJEAT), 2019, vol. 8, no. 4, pp. 696-702.

13. Value Standard and Body of Knowledge SAVE International, The Value Society, Northbrook, II, USA, June 2007, p.12

14. M. Kasi and T.J. Snodgrass, "An Introduction to Value Analysis and Value Engineering for Architect, Engineering and Builders", University of Wisconsin 1994.

15. H. Priyanto, "Pengoptimalan Value Engineering pada Tahap Disain Bangunan Gedung Di Inonesia", thesis Un-Published University of Indonesia, 2010.

16. A. Palmer,"'A Comparative Analysis of Value Management Systems In The UK, USA and Japan", CIB Beijjng International Conference, China, 21-24 October 1996.

17. L. D. Miles,' 'Technique of Value Analysis and Engineering", 3rd ed, McGraw-Hill Book Company, New York, 1972.

18. M. Kholil, B. N. Alfa, M. Hariadi, "Scheduling of House Development Project with CPM and PERT Method for Time Efficiency (Case Study : House Type 36)", IOP Conf. Series: Earth and Environmental Science, 2018, vol. 140, no 1, pp. 1-8.

19. G. Y. Abbasi and A. M. Mukattash, "Crashing PERT Network Using Mathematical Programming," International Journal of Project Management, 2001, vol. 19, no. 3, pp. 181-188.

20. A. E. Husin and B. D. Kussumardianadewi,"Cost Performance Review on Value Engineering Optimized Floor Cover Finishing Work of High Rise Office Building," International Journal of Engineering and Advance Technology (IJEAT), 2018, vol. 8, no. 2, pp. 146-154.

21. S. Atabay and N. Galipogullari, "Application of Value Engineering in Construction Project,"Journal of Traffic and Transportation Engineering, 2013, vol. 1, no. 1, pp. 39-48.

22. E. H. Al Salmi, "Value Engineering Application in Highway Design and Construction," International Road Federation Examiner, 2017, vol. 12, pp. 7-14.

23. A. E. Husin,"Implementation Value Engineering In Diaphragm Wall at High Rise Building," International Journal of Scientific Research Engineering E Technology (IJSRET), 2019, vol. 8, no. 1, pp. 16-23. 
Figures

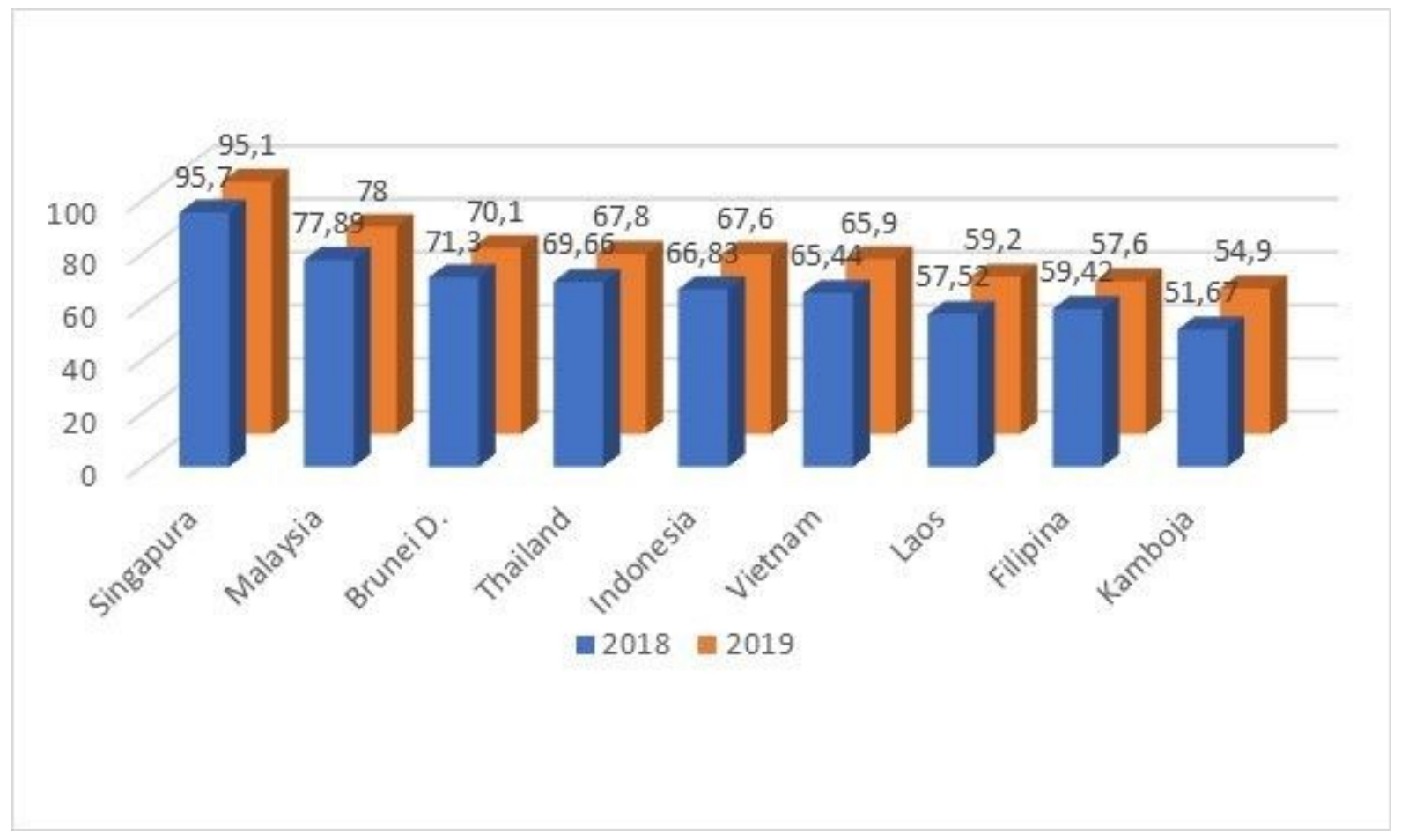

Figure 1

ASEAN Country Infrastructure Competitiveness Ranking Score [1].

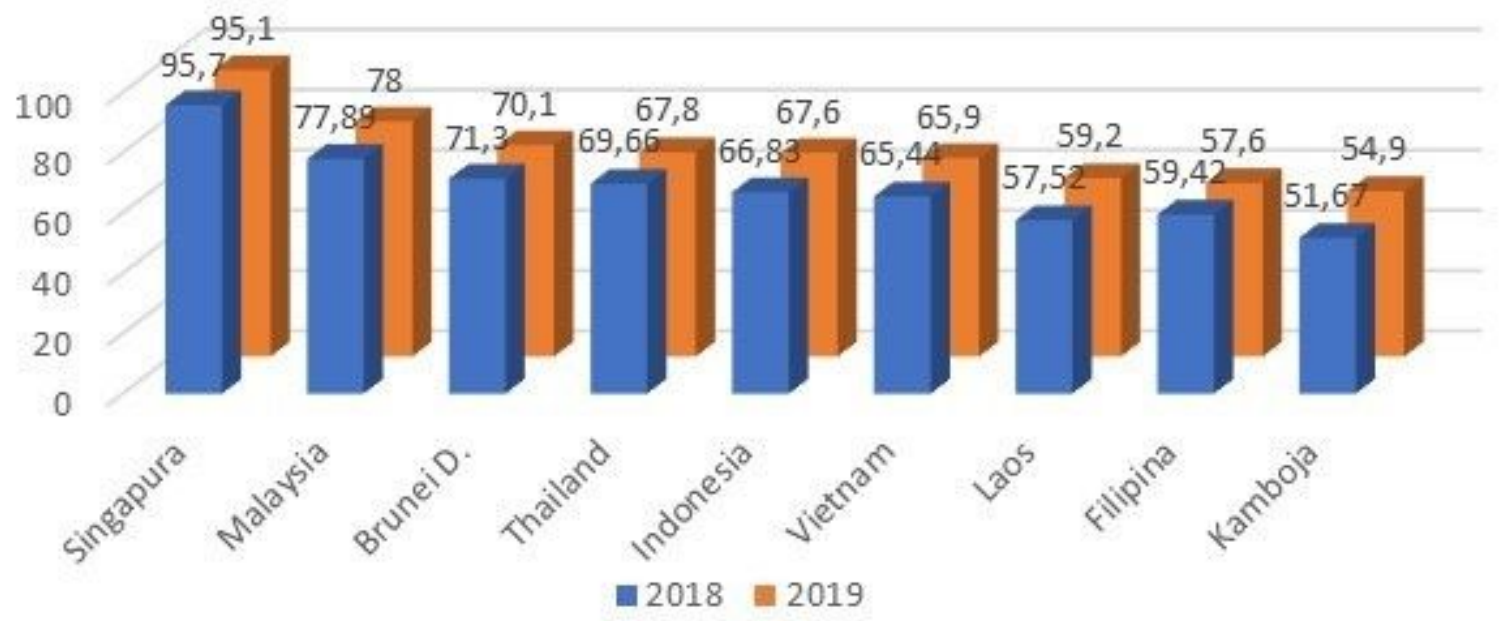

Figure 1

ASEAN Country Infrastructure Competitiveness Ranking Score [1]. 
Performance Improvement of Box Girder Construction on Toll Road Project based on

Manual Program Evaluation and Review Technique (M-PERT) and Value Engineering (VE)

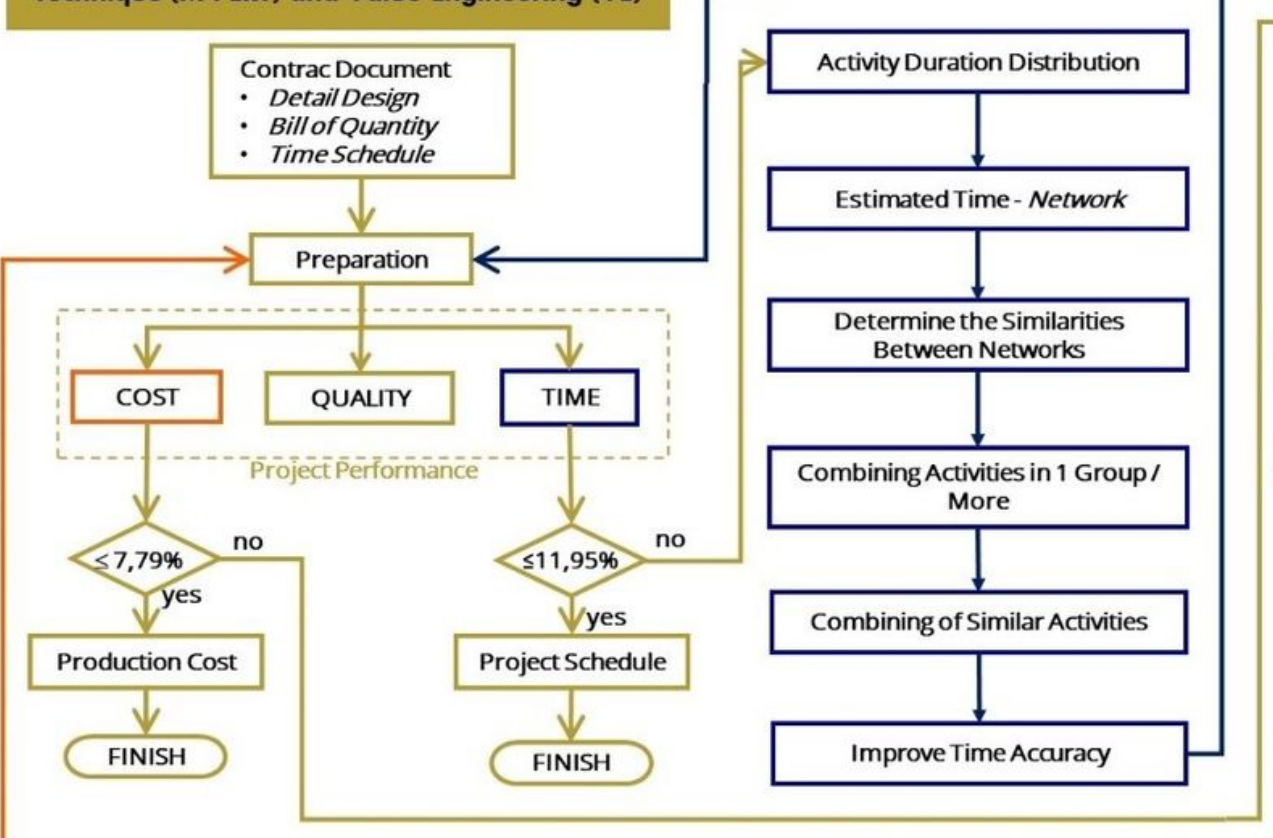

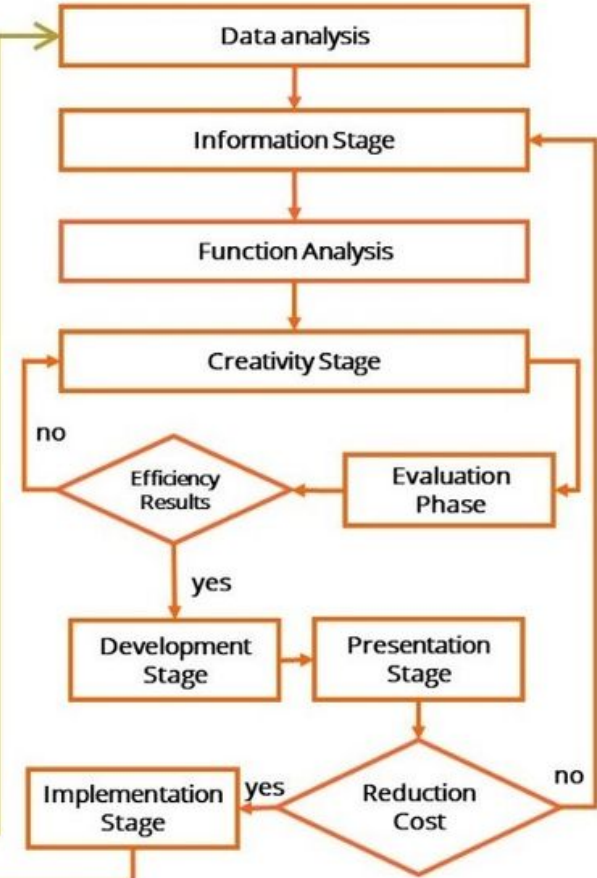

\section{Figure 2}

Flowchart of the Implementation of Time and Cost Performance Improvement Based on M-PERT and VE

Performance Improvement of Box Girder Construction on Toll Road Project based on

Manual Program Evaluation and Review Technique (M-PERT) and Value Engineering (VE)

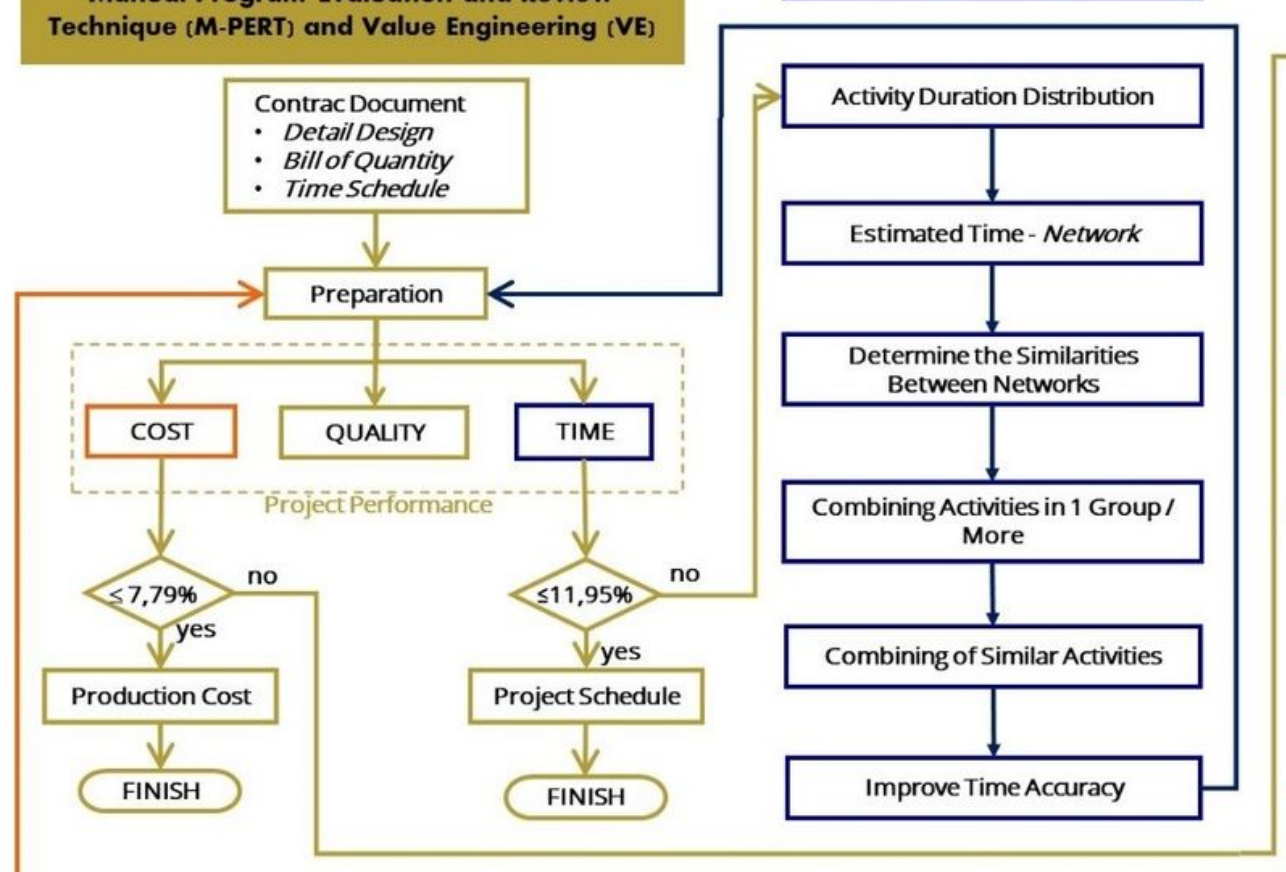

\section{METHODM-PERT}

VALUEENGINEERING

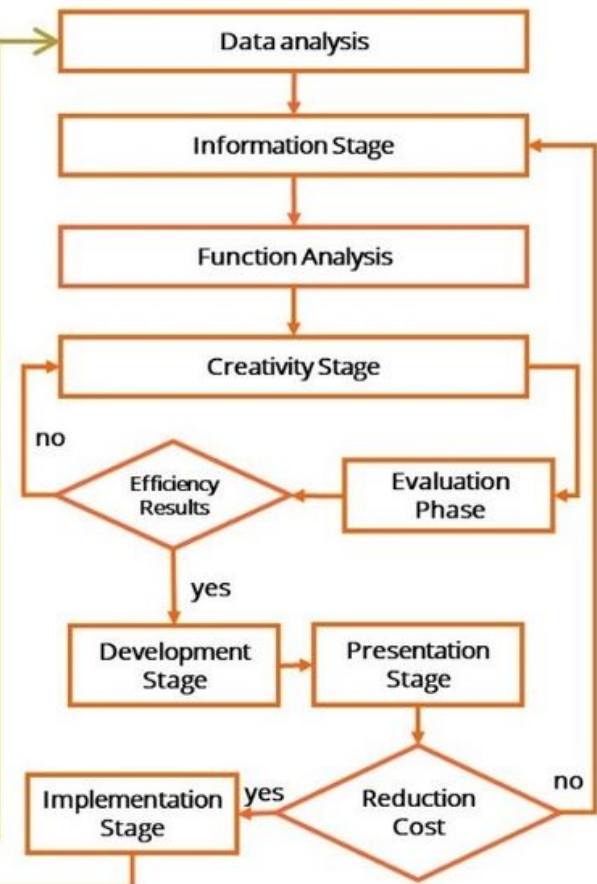

Figure 2 
Flowchart of the Implementation of Time and Cost Performance Improvement Based on M-PERT and VE

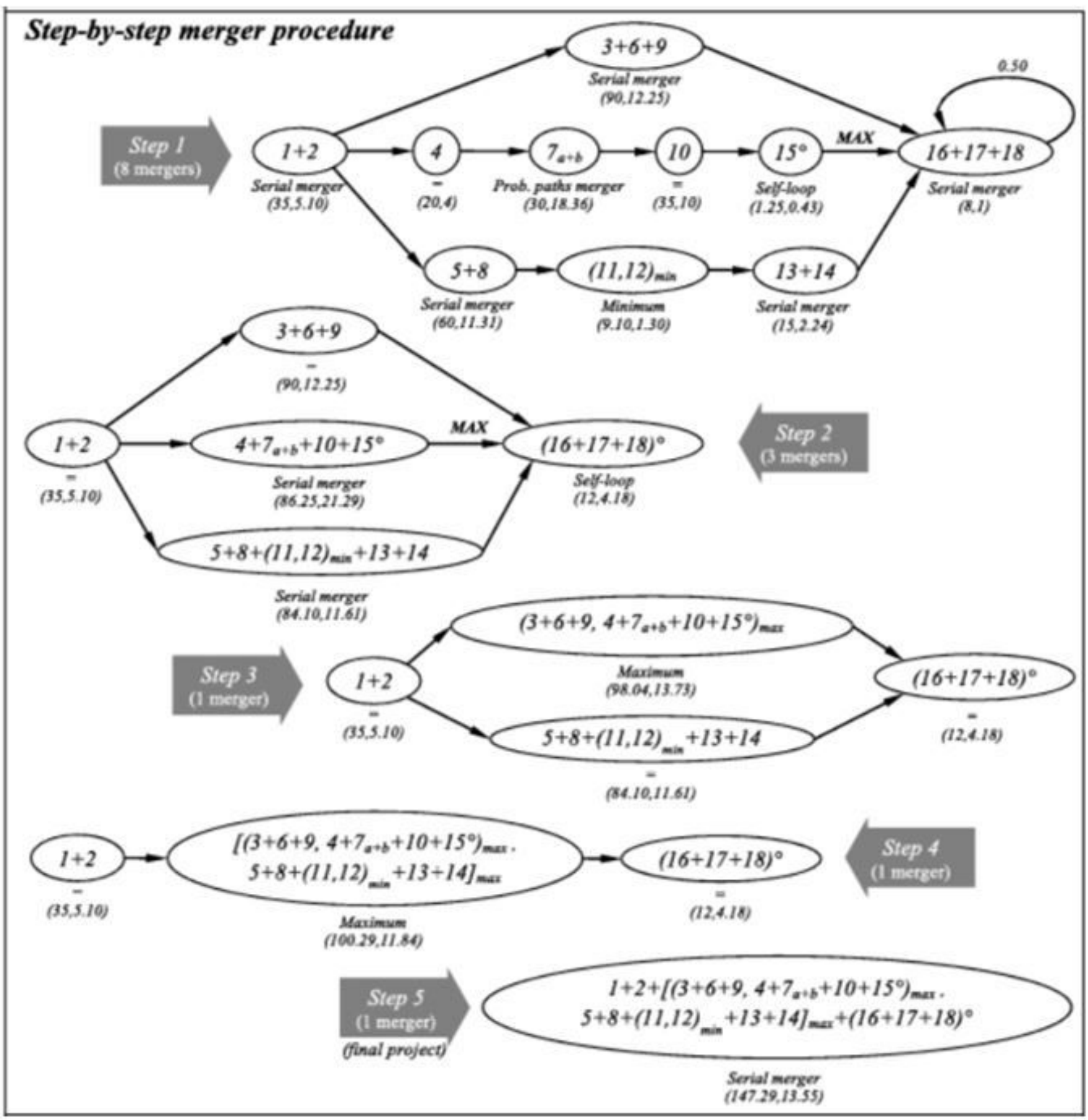

Figure 3

Activity Merger Steps [11]. 


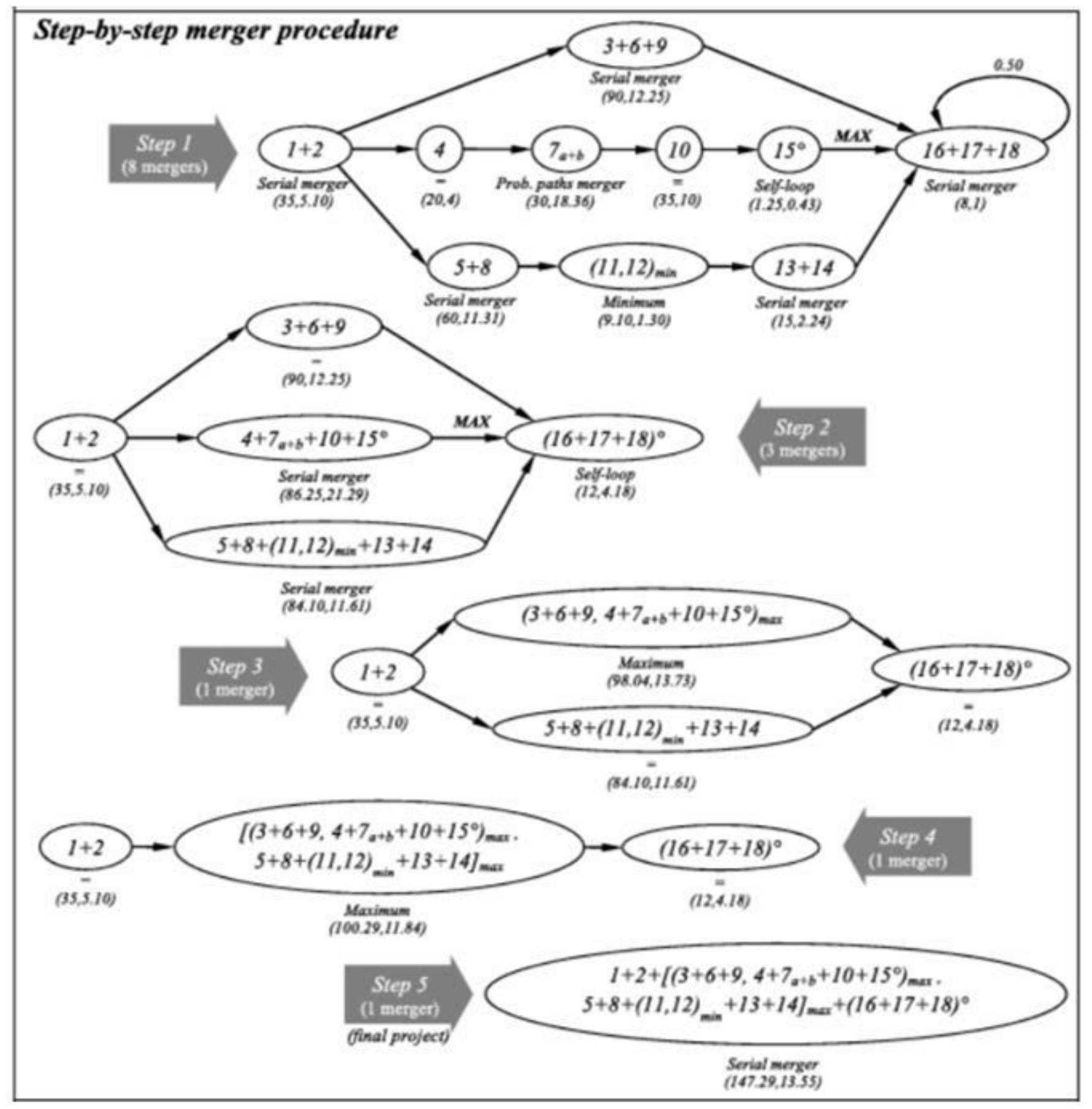

Figure 3

Activity Merger Steps [11]. 


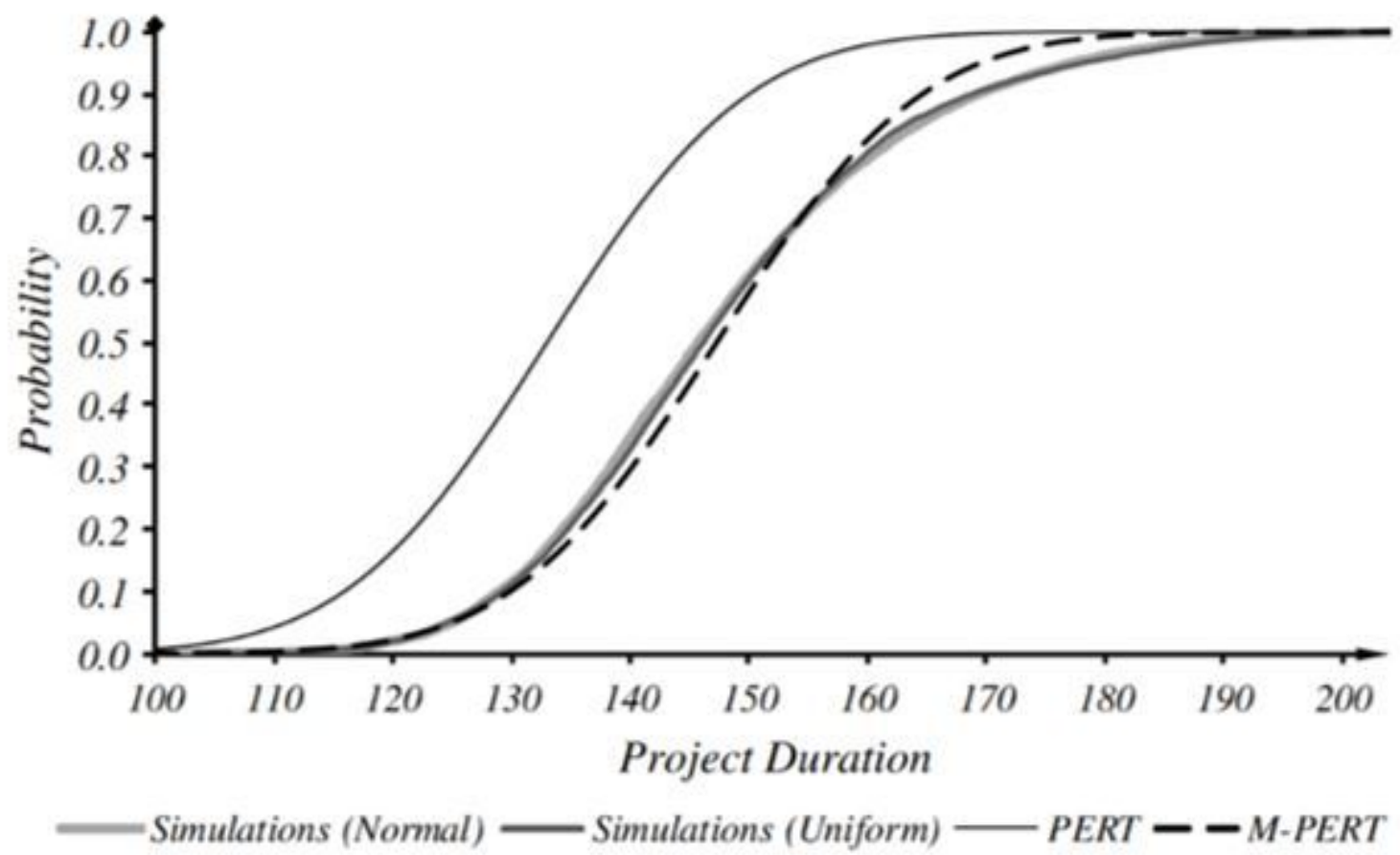

Figure 4

Comparison of the accuracy of project duration estimates between the normal, PERT, and M-PERT distributions [11].

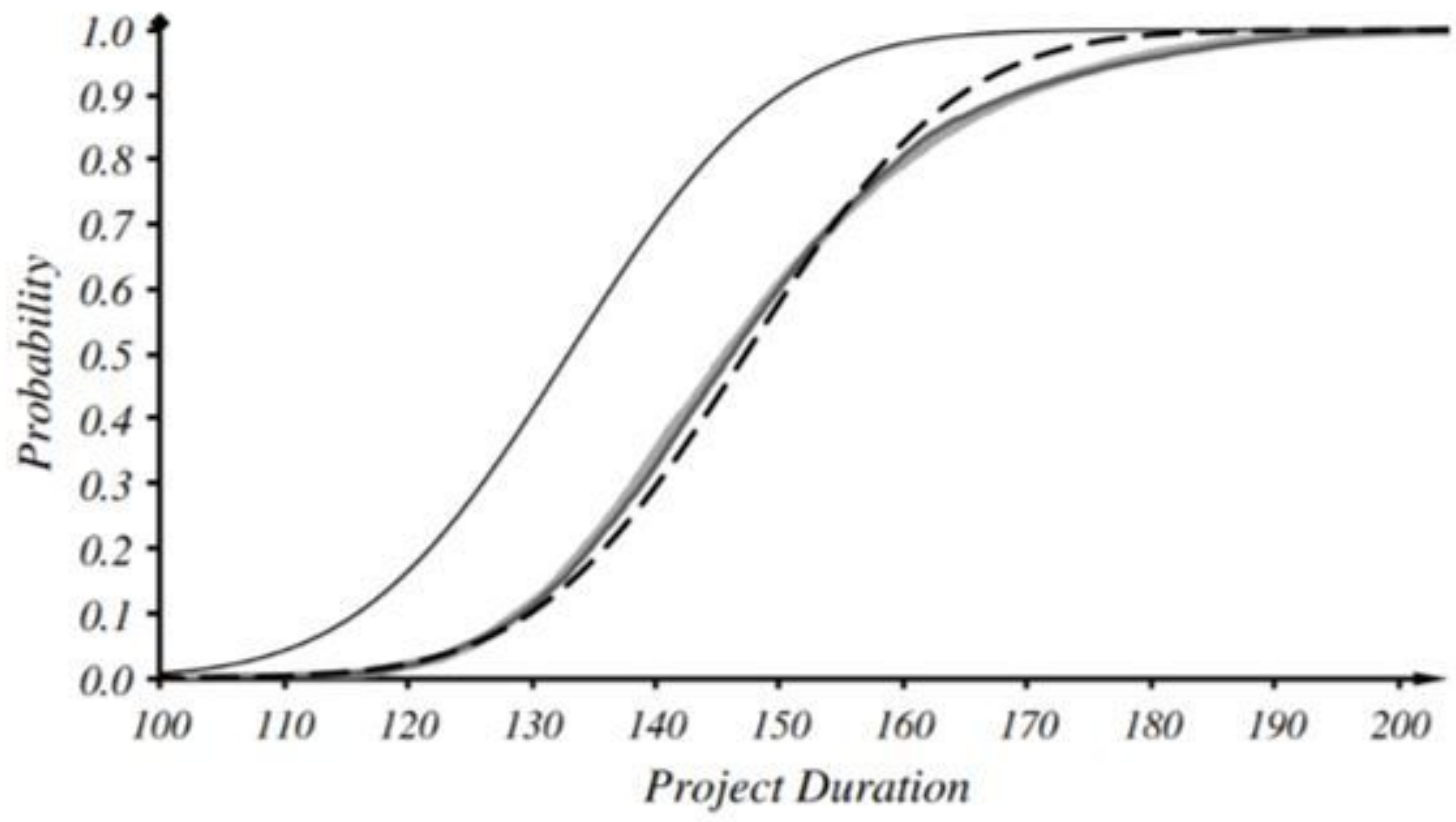

- Simulations (Normal) $\longrightarrow$ Simulations (Uniform) $\longrightarrow$ PERT - - M-PERT 
Figure 4

Comparison of the accuracy of project duration estimates between the normal, PERT, and M-PERT distributions [11].

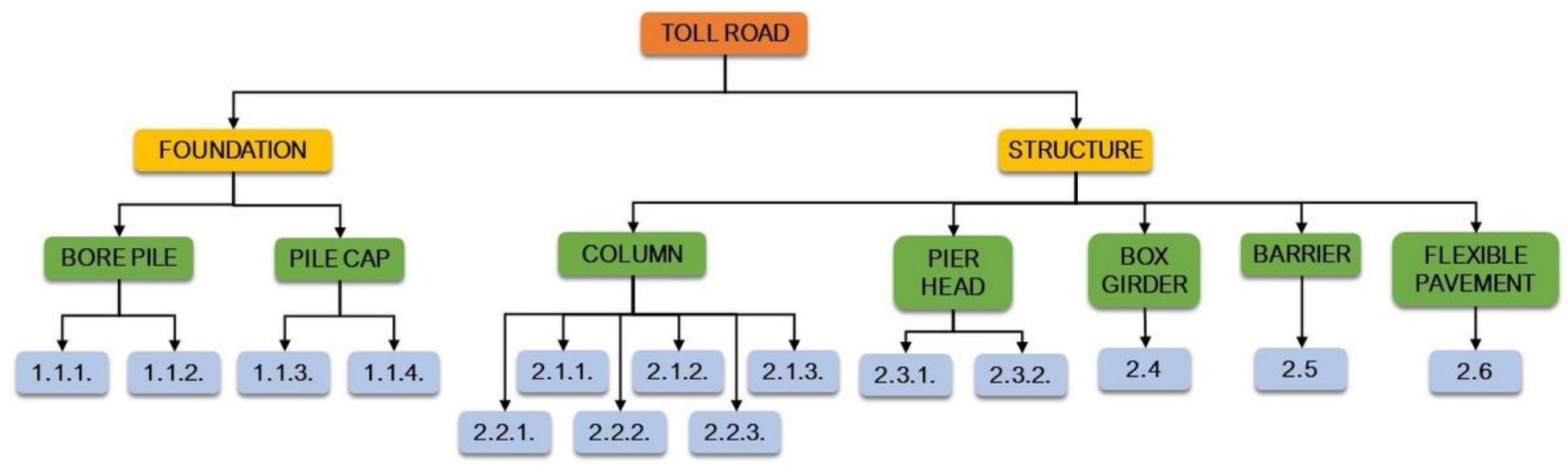

Figure 5

Bekasi - Cawang - Kampung Melayu Toll Road Construction Work Activities

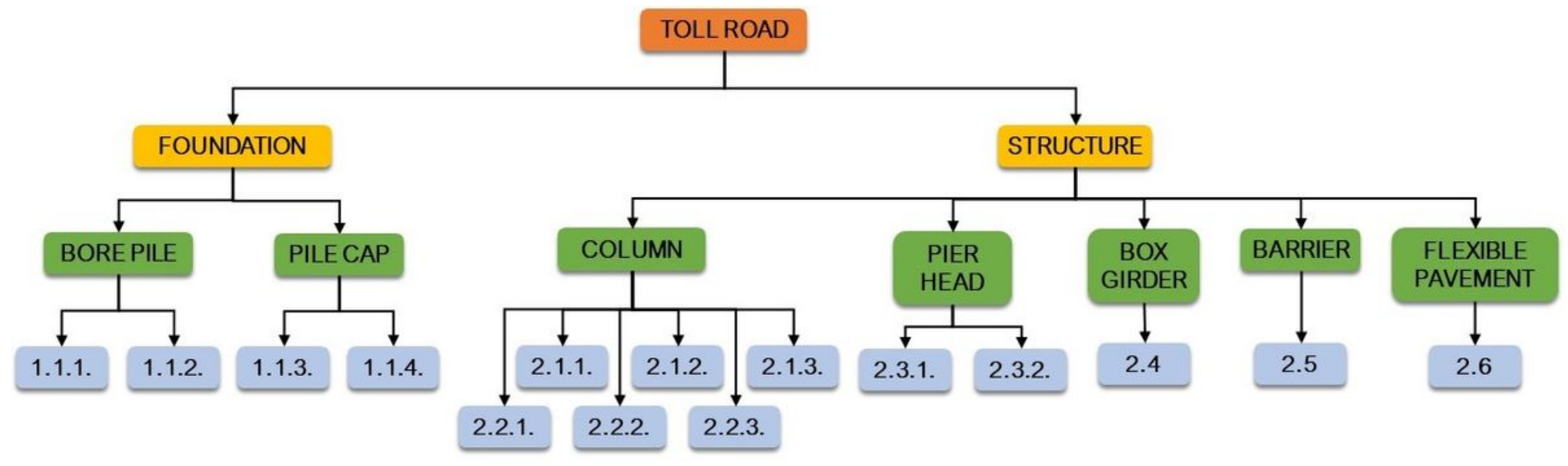

Figure 5

Bekasi - Cawang - Kampung Melayu Toll Road Construction Work Activities 


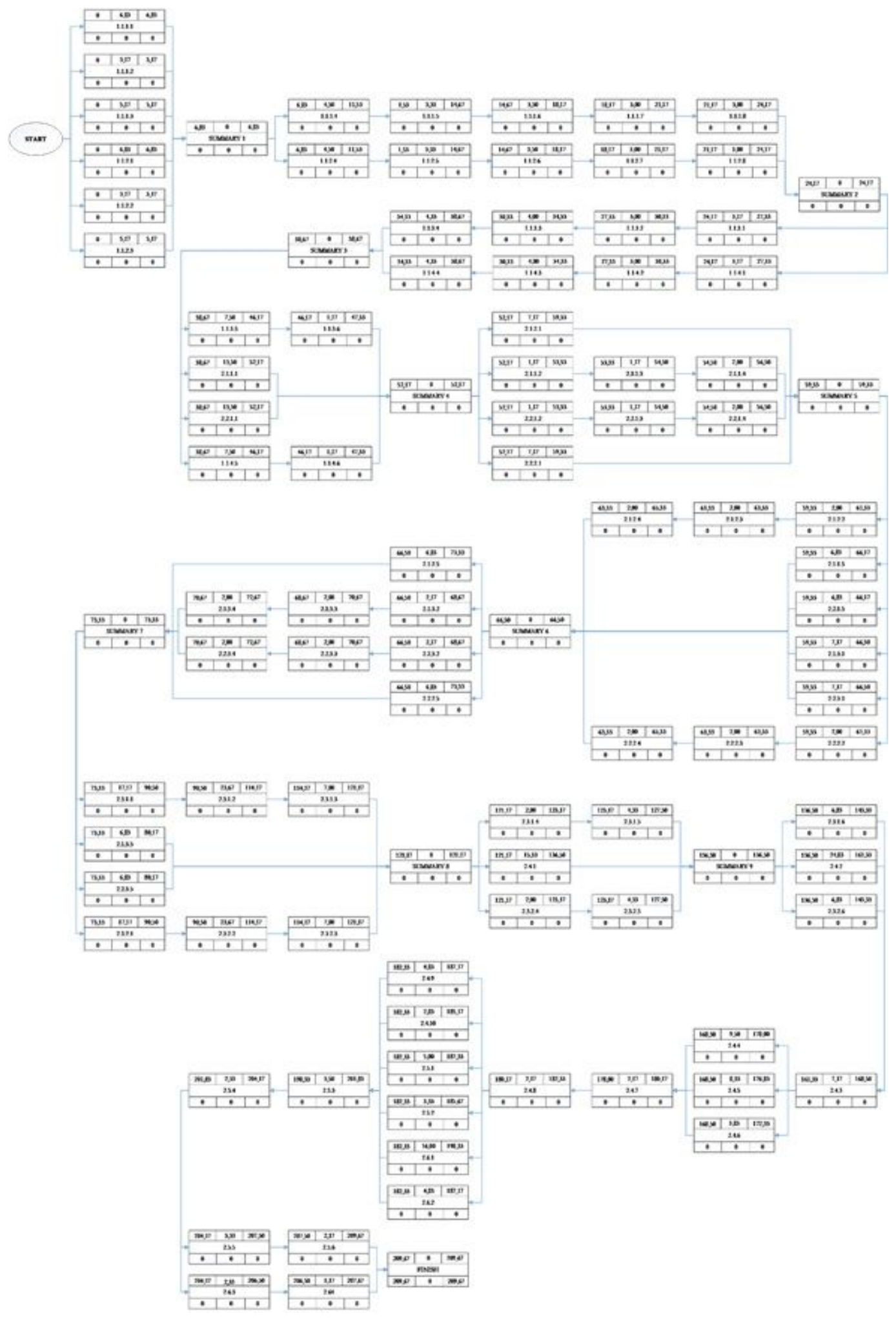

Figure 6

Precedence Diagramming Method 


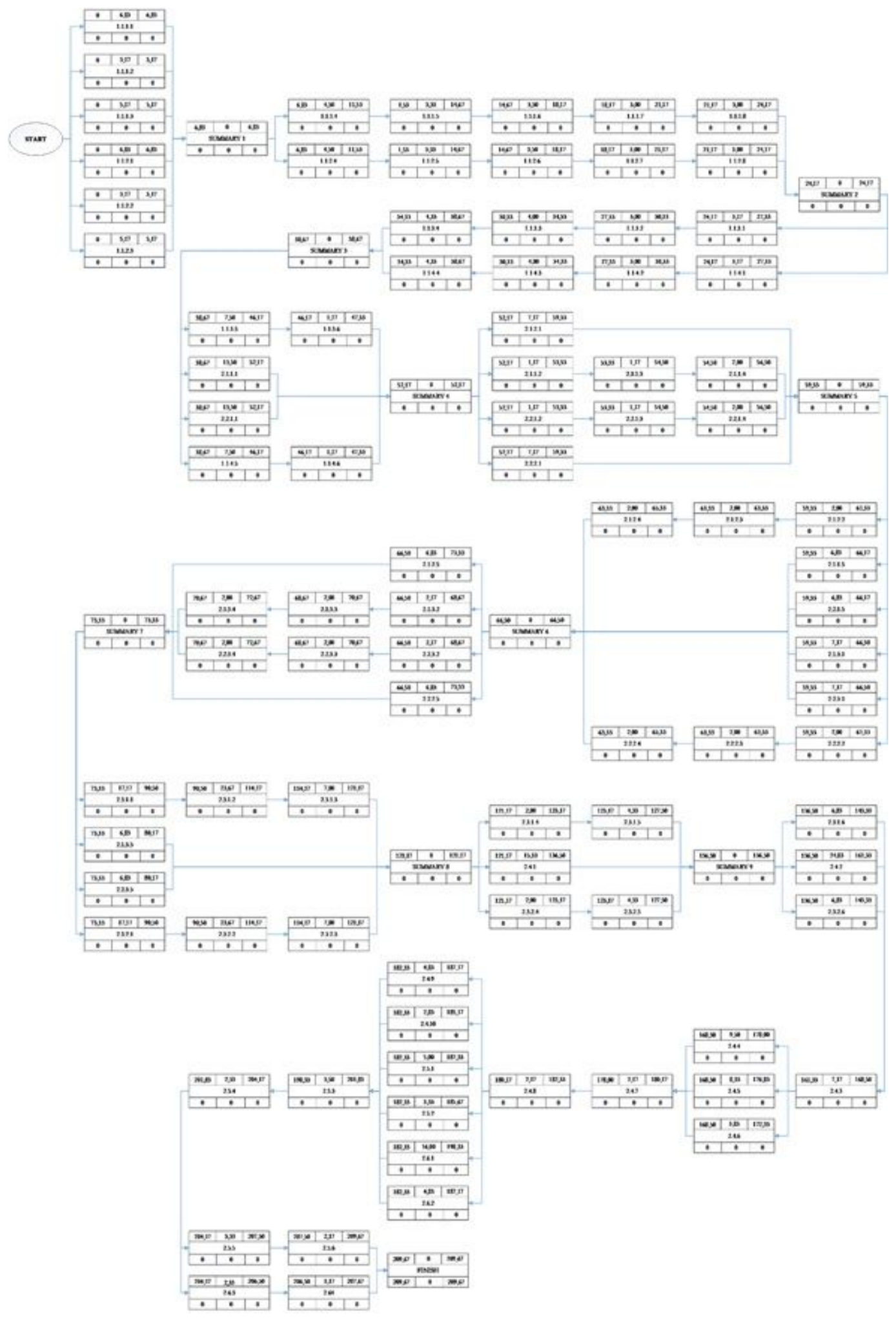

Figure 6

Precedence Diagramming Method 


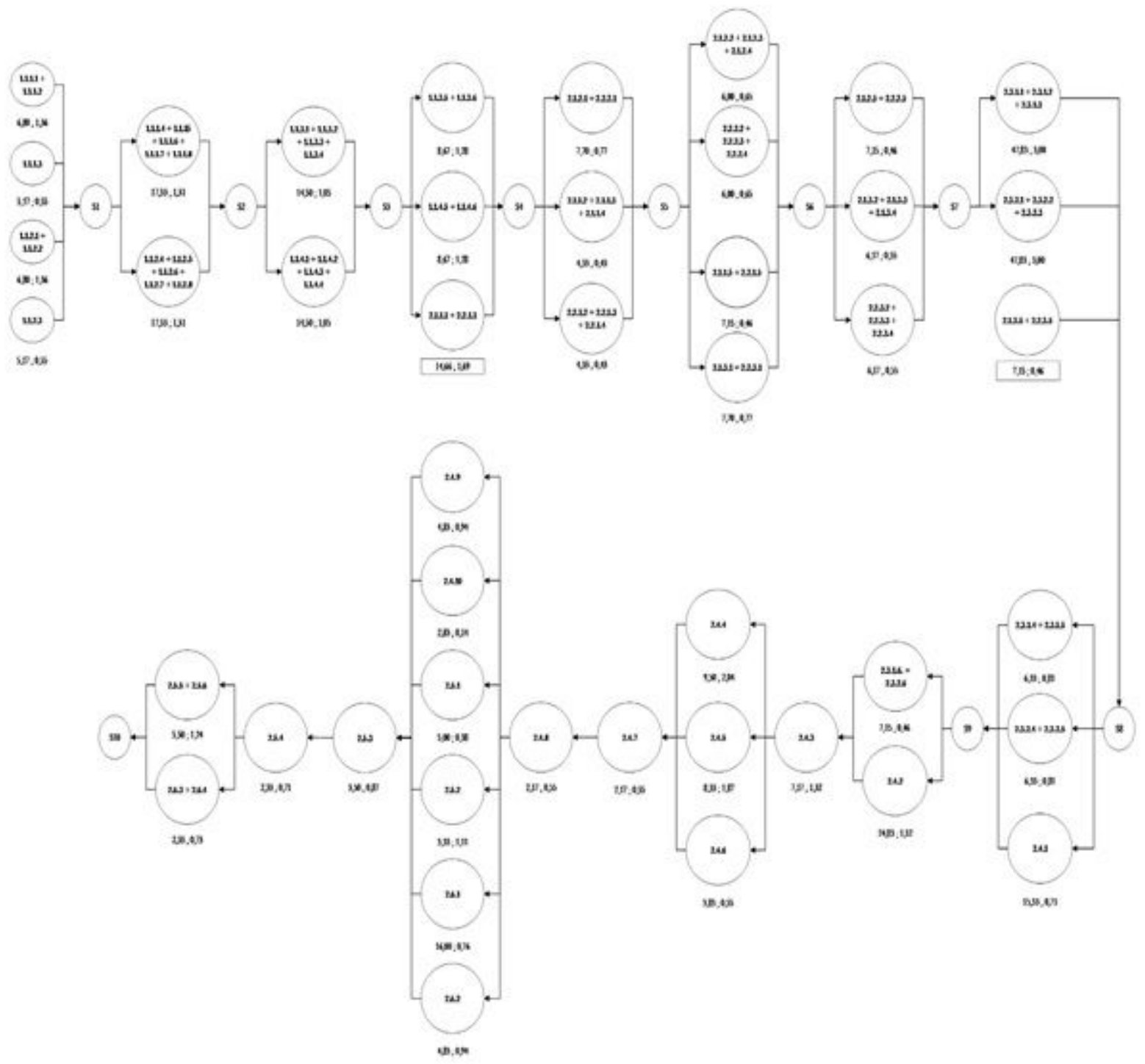

Figure 7

Diagram M-PERT Step 1 


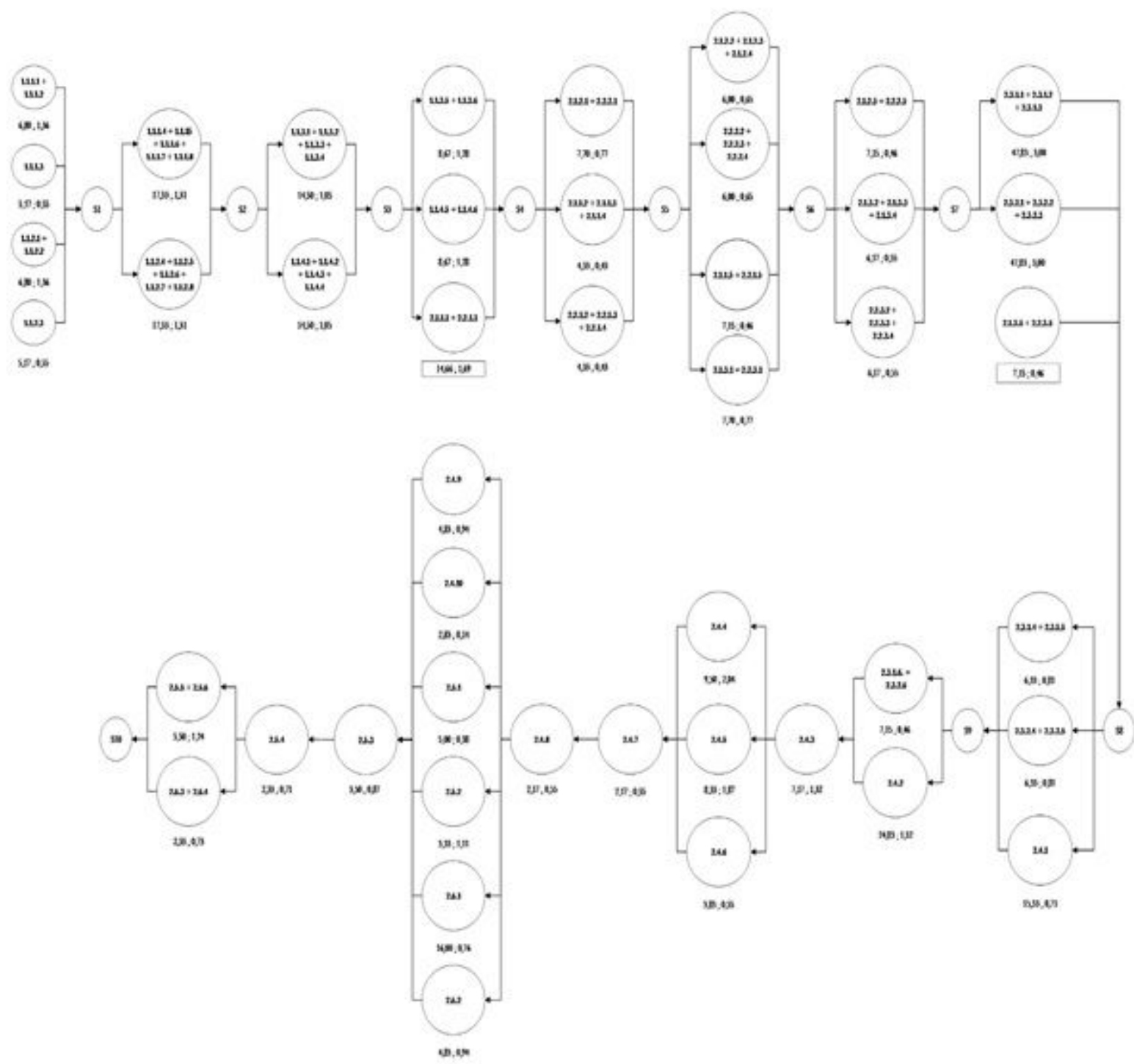

Figure 7

Diagram M-PERT Step 1

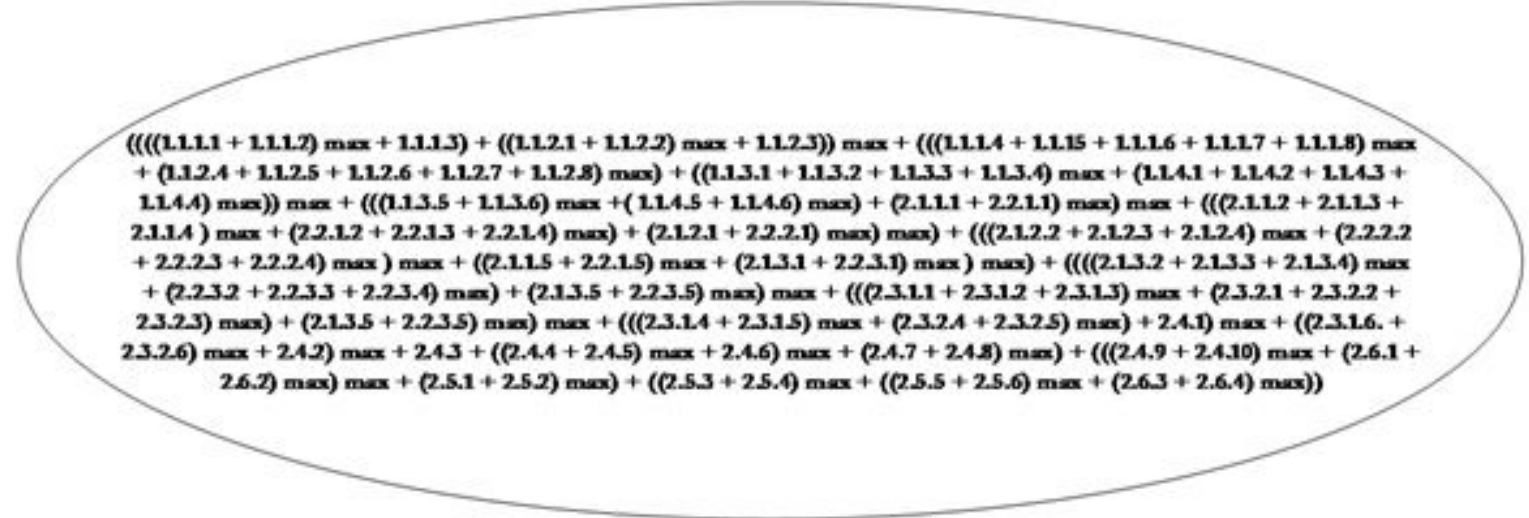

216,$52 ; 21,87$ 


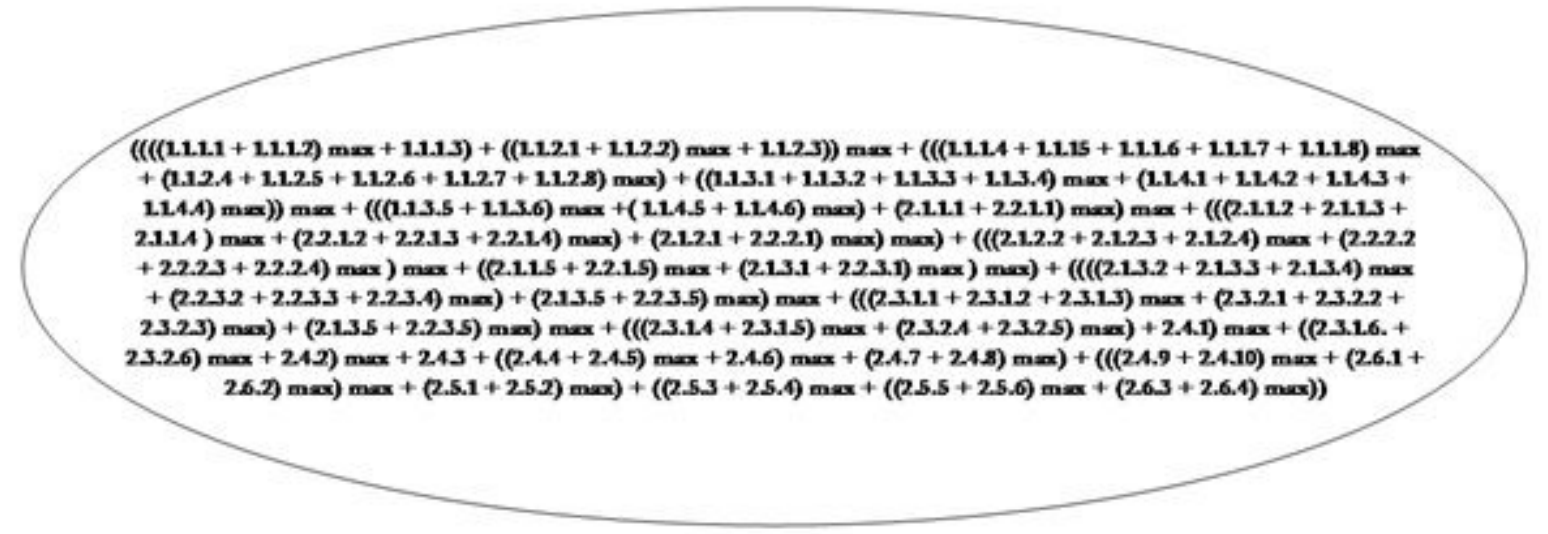

216,$52 ; 21,87$

\section{Figure 8}

Diagram M-PERT Step 5

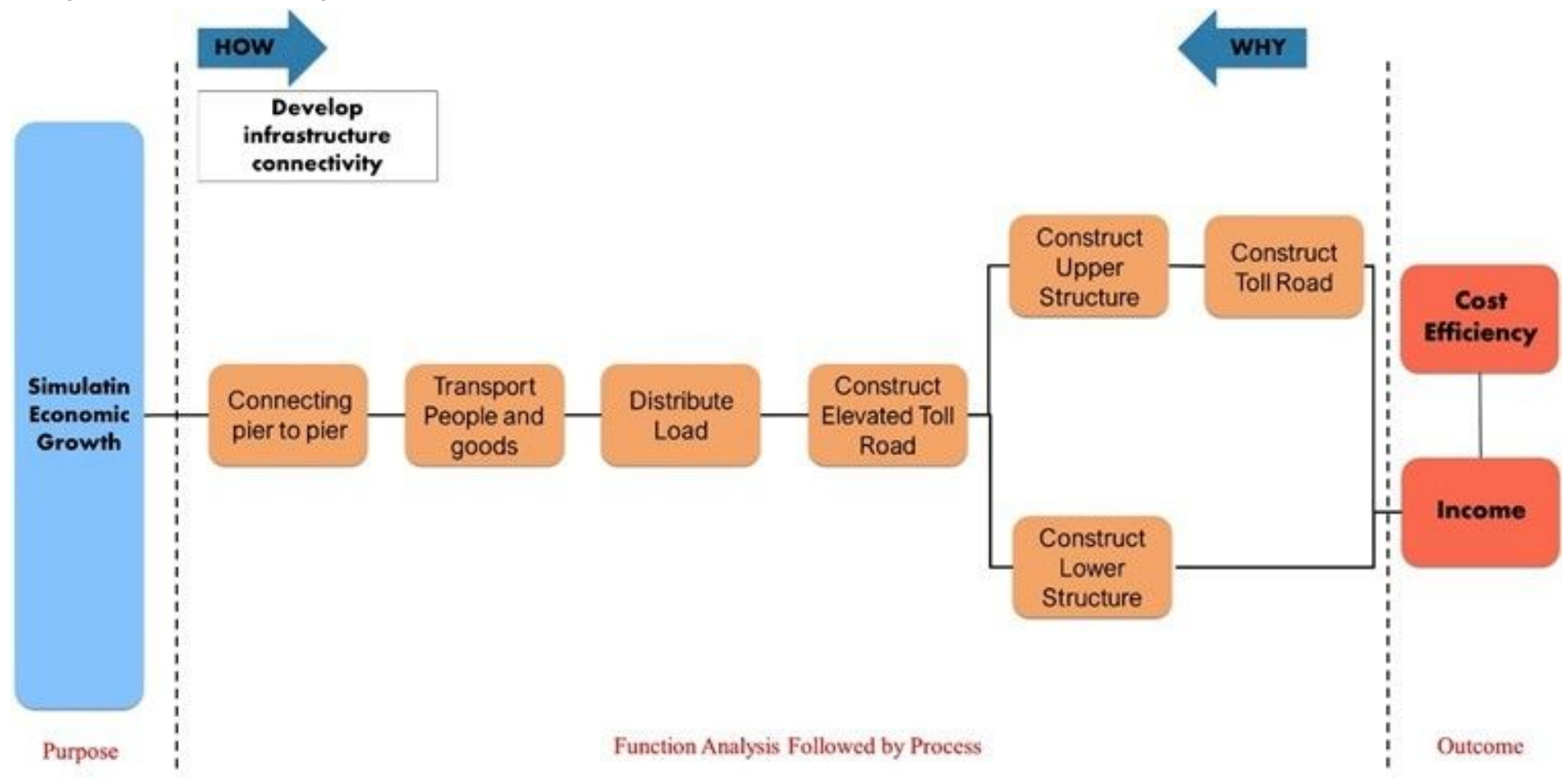

Figure 9

FAST Diagram of the Existing of the Bekasi - Cawang - Kampung Melayu Toll Road 


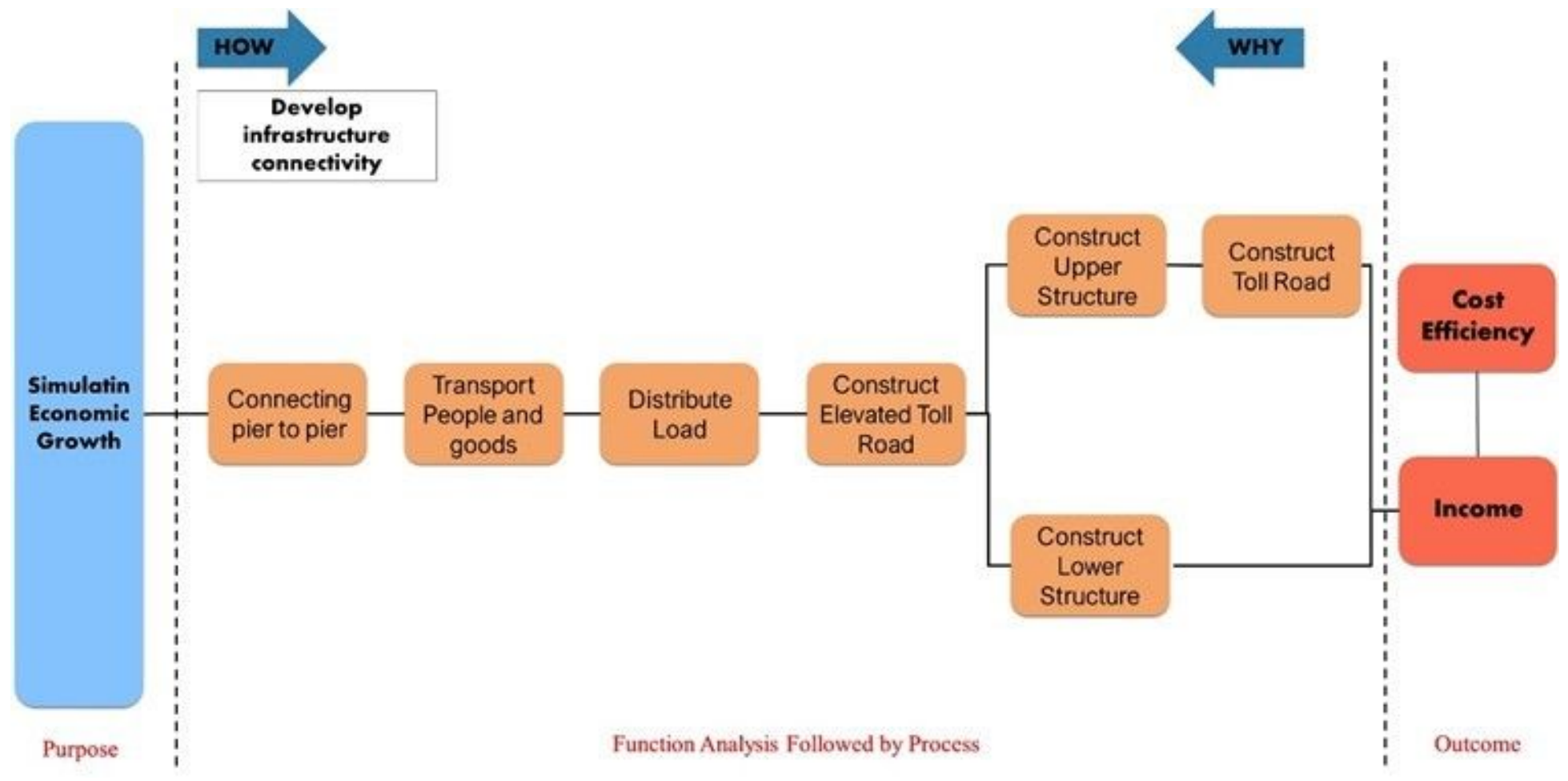

Figure 9

FAST Diagram of the Existing of the Bekasi - Cawang - Kampung Melayu Toll Road

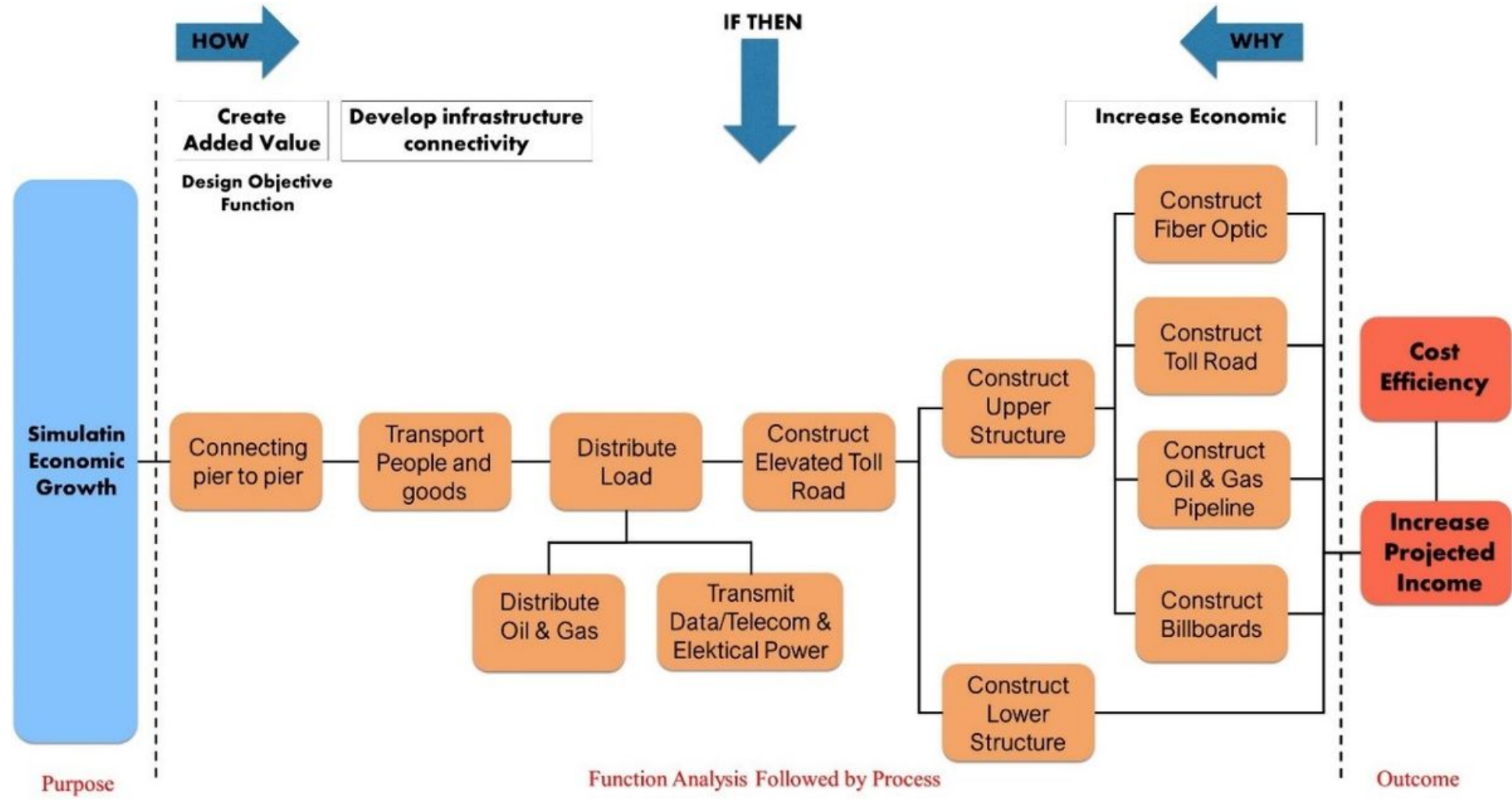

Figure 10

FAST Diagram of the Development of the Bekasi - Cawang - Kampung Melayu Toll Road 


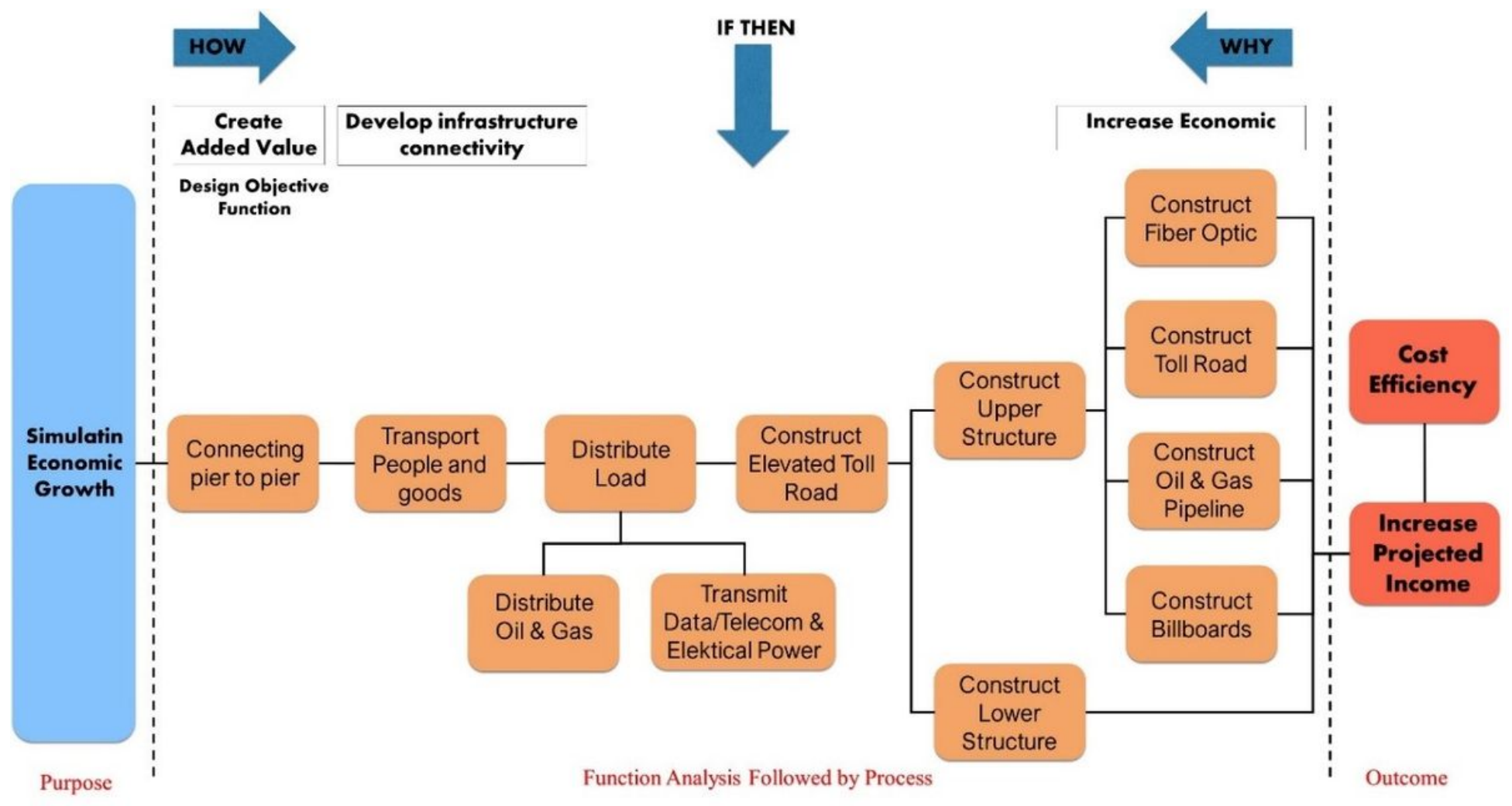

Figure 10

FAST Diagram of the Development of the Bekasi - Cawang - Kampung Melayu Toll Road 